\title{
Article \\ Optimal Allocation Model for Water Resources Coupled with Ecological Value Factors-A Case Study of Dalian, China
}

\author{
Jie Zhang ${ }^{1}$, Chong Meng ${ }^{2}$, Shugang $\mathrm{Hu}^{1, *}$ and $\mathrm{Wei}^{2}{ }^{2, *}$ \\ 1 College of Safety and Environmental Engineering, Shandong University of Science and Technology, \\ Qingdao 166590, China; zj1443024554@163.com \\ 2 College of the Environment, Beijing Normal University, Beijing 100091, China; meng157661952@hotmail.com \\ * Correspondence: husg8921@163.com (S.H.); weili@bnu.edu.cn (W.L.); Tel.: +86-159-6426-9810 (S.H.); \\ +86-139-1012-3723(W.L.)
}

check for

updates

Citation: Zhang, J.; Meng, C.; Hu, S.; Li, W. Optimal Allocation Model for Water Resources Coupled with Ecological Value Factors-A Case Study of Dalian, China. Water 2022, 14, 266. https://doi.org/10.3390/ w14020266

Academic Editors: Alban Kuriqi and Luis Garrote

Received: 14 December 2021

Accepted: 15 January 2022

Published: 17 January 2022

Publisher's Note: MDPI stays neutral with regard to jurisdictional claims in published maps and institutional affiliations.

Copyright: () 2022 by the authors Licensee MDPI, Basel, Switzerland. This article is an open access article distributed under the terms and conditions of the Creative Commons Attribution (CC BY) license (https:// creativecommons.org/licenses/by/ $4.0 /)$.

\begin{abstract}
The surface water ecosystem has important ecological value and plays an important supporting and guarantee role in the sustainable development of human society. In this study, an inexact two-stage stochastic programming (ITSP) model was developed for supporting water resource allocation for the four main water sectors (industry, municipal, agriculture, and ecological environment). Several scenarios corresponding to different flow patterns, which reflect different probabilities of water resource availability and environmental carrying capacity, were examined. On the basis of traditional water resource allocation, this model adds consideration of ecological value factors, which is conducive to the synergistic efficiency of socio-economic and ecological water consumption. Results revealed that the water resource carrying capacity, ecological value factors, and water environmental capacity are the main factors affecting the optimal allocation of water resources. Furthermore, the optimal allocation scheme for water resources coupled with ecological value factors were determined to realize the coordinated development of social economic benefits and ecological benefits. The current study findings are of great significance for establishing a rational water resource management system for water resource exploitation and utilization. This model can be used to guide various departments in Dalian to formulate an optimal water resources allocation scheme by considering ecological value factors, and provide a basis for realizing the coordinated development of Dalian's socio-economic development goals, water resource utilization, and environmental quality improvement.
\end{abstract}

Keywords: inexact two-stage stochastic programming; water management; ecological value factor; water resource allocation

\section{Introduction}

Water resources are the lifeline of social progress and economic development. However, in today's world, social development and progress, population expansion, and overexploitation of water resources have caused a shortage of fresh water resources [1]. The optimal allocation of water resources is an important means to coordinate the relationship between supply and demand of water resources, improve the utilization of water resources, and coordinate the conflicts among water consuming departments, particularly in areas with water shortages [2-4]. Therefore, it is necessary to optimize the allocation of water resources in water-scarce areas. With the increasing demand for water quality improvement, water demand has become important for regional water resource optimization and allocation $[5,6]$. However, the value created by the water ecosystem cannot be presented intuitively, the conventional optimal allocation of urban water resources pays more attention to the economic output of water consumption and does not fully consider the ecological value, which is not conducive to the synergistic efficiency of socio-economic and ecological water consumption. Therefore, it is necessary to increase the direct consideration of ecological value factors while considering the optimal allocation of water resources. In addition, there are many uncertainties in the optimal allocation of water resources, such as variable 
availability of water resources, demand, and development of water treatment technologies, which make it difficult to select the optimal allocation method. Therefore, under the background of promoting the construction of urban ecological civilization, the optimal allocation of water resources presents challenges in coordinating the ecological value and dealing with various uncertain factors [7].

Interval-parameter programming, fuzzy programming, and stochastic programming are common methods for water resources allocation under uncertainty [8-12]. For example, Huang and Locks [13] were the first to propose the inexact two-stage stochastic programming (ITSP) to deal with uncertain information in interval-valued and random variable representations. Under the framework of the ITSP method, various advanced models are proposed and applied to water resources management [14]. Maqsood [15] presented an interval-parameter fuzzy two-stage stochastic programming (IFTSP) method for the planning of water resource management systems under uncertainty; Li et al. [16] selected an interval-fuzzy two-stage stochastic quadratic programming model with the objective of maximum benefits to have the best irrigation water allocation scheme. Xie [13] developed an inexact, two-stage, water resources management model for multi-regional water resources planning in the Nansi Lake Basin, China. In the ITSP, an initial decision is made before the random events. After future uncertainties are resolved and the values of the random variables are revealed, a second decision is made that minimizes penalties due to any infeasibilities [17]. It can be seen that ITSP is an effective method for optimal allocation of water resources under uncertain conditions.

As the leading revitalization and famous coastal industrial city in Northeast China, Dalian lacks freshwater resources. With the development of the urban social economy and the improvement of the ecosystem, the demand for water resources continues to grow rapidly and presents intensified competition. It is difficult to coordinate water use among industrial, municipal, and ecological environment sectors [18]. Under the overall objective of coordinating urban social and economic development and improving the living environment, this study intended to reflect different probabilities of water resource availability and environmental carrying capacity in different flow scenarios. An ITSP model was constructed by coupling the ecological value factors, which was more comprehensively considering the impact of ecological value factors on the optimal allocation results of water resources. The four major urban water departments in Dalian, including the industry, urban community, agriculture, and ecological environment, were studied to discuss the optimal allocation mode and method for urban water resources, coordinate the needs and value factors for the improvement of the ecosystem, and realize the coordinated development of ecological value and social and economic benefits.

Therefore, aiming at the dual constraints of water resource shortage and water environment quality and based on the principle of achieving the coordination of ecological value and social and economic benefits, a general framework for establishing an ITSP for the optimal allocation of water resources in Dalian under uncertain conditions is proposed (Figure 1). The model considers constraints such as ecological area and water consumption, as well as available water resources and water environment capacity, and combines ecological value benefits with water resource management to provide Dalian with a relatively reasonable water resource allocation plan. Our study findings are of great significance for establishing a rational water resource management system for water resource exploitation and utilization, as well as water ecosystem protection, and provide a basis for realizing the coordinated development of Dalian's socio-economic development goals, water resource utilization, and environmental quality improvement. 


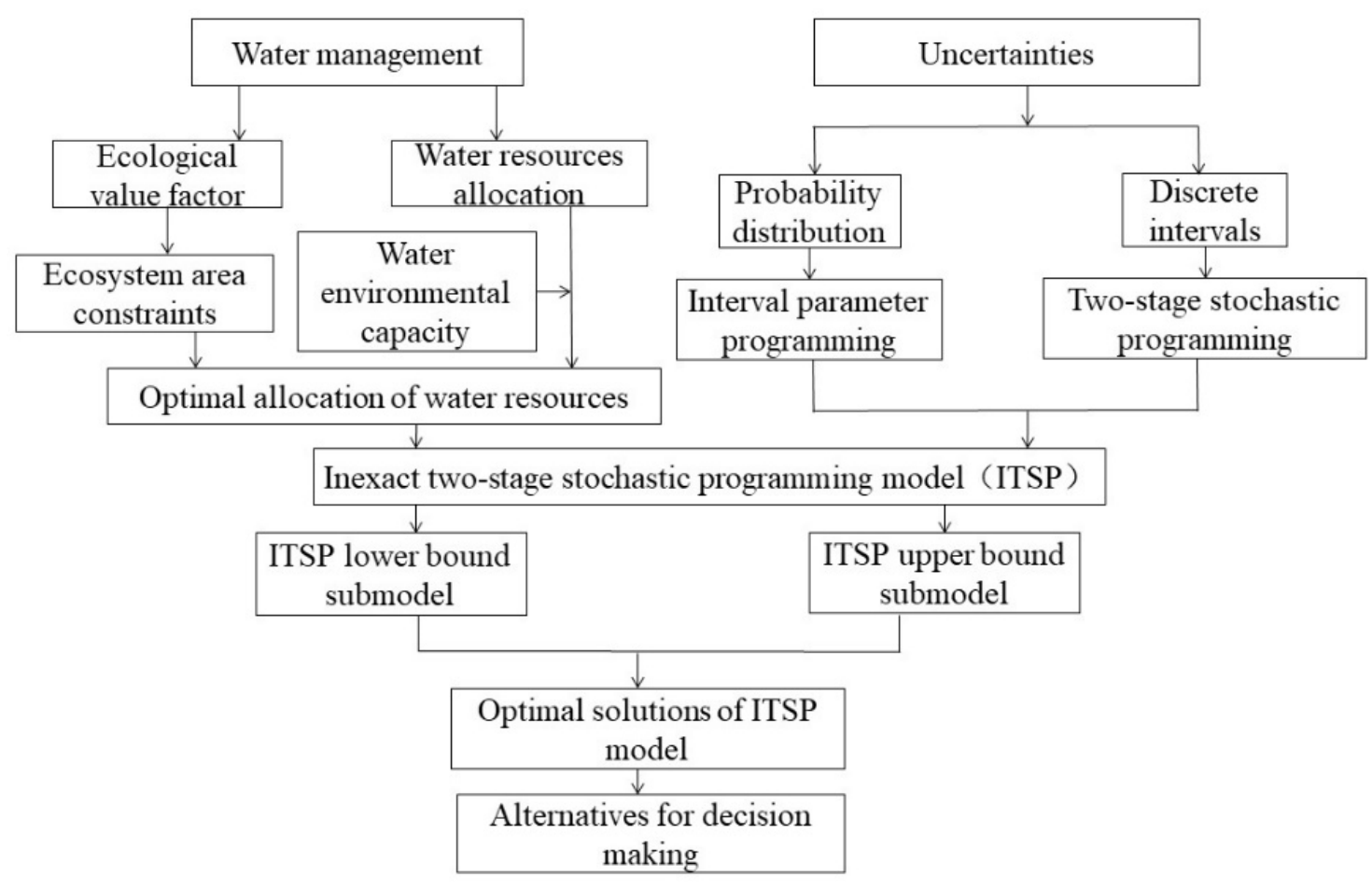

Figure 1. Framework for the inexact two-stage stochastic programming (ITSP) model.

\section{Study Area and Division of Integrated Zones}

Dalian covers $43,014 \mathrm{~km}^{2}$, of which $13,739 \mathrm{~km}^{2}$ is land. The city's multi-year average total water resources are $3.14 \times 10^{9} \mathrm{~m}^{3}$, of which surface water resources are $3.05 \times 10^{9} \mathrm{~m}^{3}$, and the regional distribution, as well as inter- and intra-annual changes in the runoff in each basin, are extremely uneven, making it a water-poor area [19]. There are more than 300 rivers in the urban area, which are divided into the river systems along the Yellow Sea in eastern Liaodong and the river systems along the Bohai Sea in the eastern Liaodong Bay. There are 57 rivers that flow into the sea, along with a catchment area of more than $2.00 \times 10^{7} \mathrm{~m}^{2}$ [20]. There are 69 reservoirs of various types, with a total annual storage capacity of $1.32 \times 10^{9} \mathrm{~m}^{3}$, of which 22 are the main drinking water sources. Dalian is rich in wetland resources, with a total area of about $3.58 \times 10^{9} \mathrm{~m}^{2}$, including $2.42 \times 10^{9} \mathrm{~m}^{2}$ of offshore and coastal wetlands, $1.04 \times 10^{9} \mathrm{~m}^{2}$ of artificial (coastal) wetlands, $1.15 \times 10^{8} \mathrm{~m}^{2}$ of river wetlands, and $3.00 \times 10^{8} \mathrm{~m}^{2}$ of marsh wetlands.

Figure 2 shows the geographical position and study regions of Dalian. To reflect different water environmental functions and water resource utilization in terms of time and space, the study area was divided into 37 integrated zones $(\mathrm{i}=1-37$ represent $\mathrm{I}, \mathrm{II}$, III, IV, V, VI, VII, VIII, IX, X, XI, XII, XIII, XIV, XV, XVI, XVII, XVIII, XIX, XX, XXI, XXII, XXIII, XXIV, XXV, XXVI, XXVII, XXVIII, XXIX, XXX, XXXI, XXXII, XXXIII, XXXIV, XXXV, $X X X V I$, and $X X X V I I)$ and six administrative regions $(i=1-6$ represent four districts (Xigang, Shahekou, Ganjingzi, and Zhongshan), as well as Lvshunkou, Jinpu, Wafangdian, Pulandian, and Zhuanghe). Figure 3 shows the relationship between regional pollutant emissions and water distribution, including pollutant emission directions and proportions. The values show the proportion of pollutant emissions generated from region $\mathrm{j}$ and discharged into the water environment zone i. 


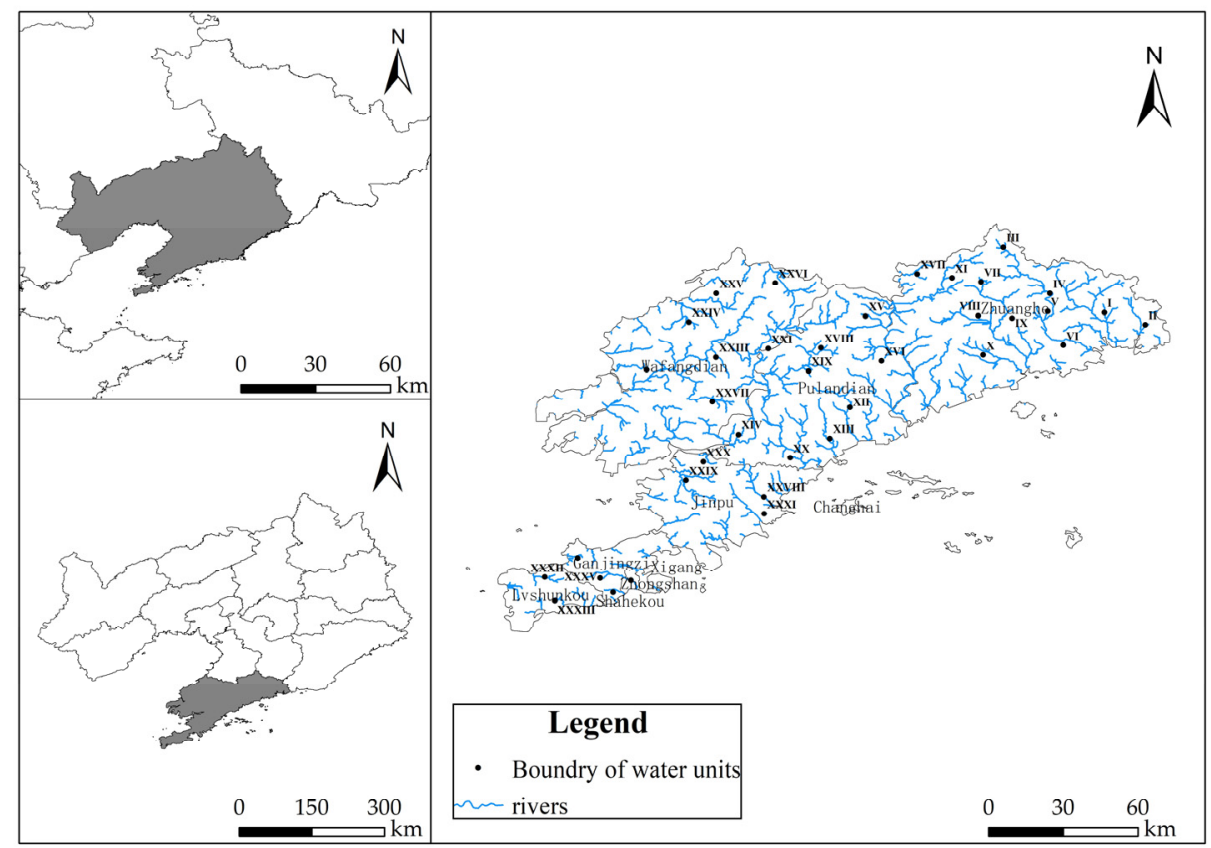

Figure 2. Geographical position and study regions of Dalian.

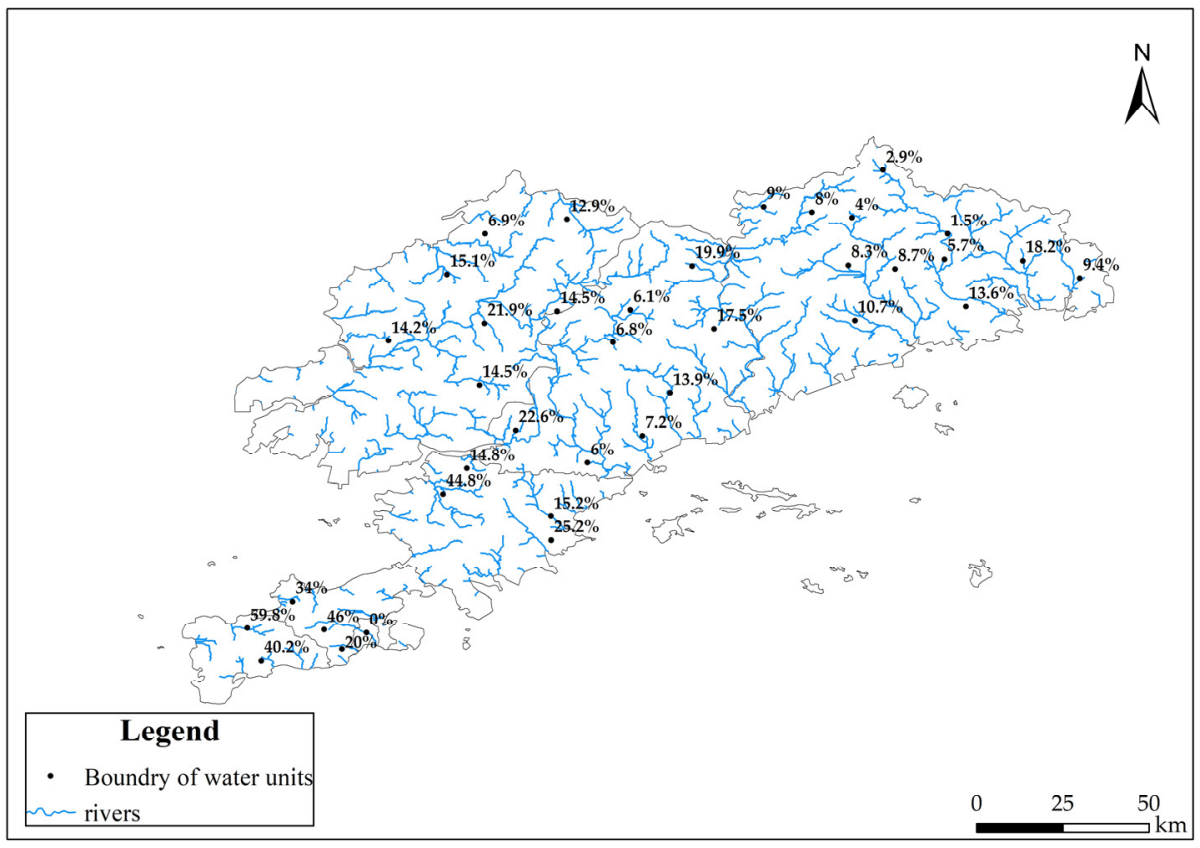

Figure 3. Relationship between regional pollutant emissions and water distribution.

\section{Model Formulation}

\subsection{Model Development}

It is often necessary to combine two-stage stochastic programming (TSP) [21] with Interval Linear Programming (ILP) to deal with uncertain factors in practical problems. Using the maximization problem as an example, the ILP is combined with the TSP to obtain the interval two-stage stochastic optimization model (ITSP), which can be expressed as:

$$
\operatorname{maxf}^{ \pm}=\mathrm{c}^{ \pm} \mathrm{x}^{ \pm}-\sum_{\mathrm{s}=1}^{\mathrm{N}} \mathrm{p}_{\mathrm{s}} \mathrm{q}\left(\mathrm{y}^{ \pm}, \mathrm{w}_{\mathrm{s}}^{ \pm}\right)
$$


and

$$
\begin{gathered}
\mathrm{A}^{ \pm} \mathrm{x}^{ \pm} \leq \mathrm{b}^{ \pm} \\
\mathrm{T}\left(\omega_{\mathrm{s}}^{ \pm}\right) \mathrm{x}^{ \pm}+\mathrm{W}\left(\omega_{\mathrm{s}}^{ \pm}\right) \mathrm{y}^{ \pm}=\mathrm{h}\left(\omega_{\mathrm{s}}^{ \pm}\right) \\
\mathrm{x}^{ \pm} \geq 0, \mathrm{y}\left(\omega_{\mathrm{s}}^{ \pm}\right) \geq 0
\end{gathered}
$$

Model 1 can be solved by transforming into sub-models of upper bound and lower bound objective functions through an interactive algorithm [14]. Then, the optimal solutions for Model 3 can be obtained as $\mathrm{f}_{\text {jopt }}^{ \pm}=\left[\mathrm{f}_{\text {jopt }}^{-} \mathrm{f}_{\text {jopt }}^{+}\right], \mathrm{x}_{\text {jopt }}^{ \pm}=\left[\mathrm{x}_{\text {jopt }}^{-}, \mathrm{x}_{\text {jopt }}^{+}\right]$and $\mathrm{y}_{\text {lsopt }}^{ \pm}=\left[\mathrm{y}_{\text {lsopt }}^{-} \mathrm{y}_{\text {lsopt }}^{+}\right]$. For more details, refer to $[14,22]$.

The research planning period will last until 2035 and will be divided into three phases: 2021-2025 (phase I), 2026-2030 (phase II), and 2031-2035 (phase III). Three flow scenarios are designed as low, medium, and high, reflecting different probabilities of water resource availability and environmental carrying capacity with different flow scenarios. The ecosystem is a prerequisite for economic and social development, and the ecological value needs to be taken into account while optimizing the allocation of water resources to achieve synergy between ecological and water use benefits. Model ecological benefits primarily include the value of ecosystem-regulating services, which can be defined as the sum of the value of ecosystems for sustainable economic and social development and human well-being [23]. This study considers four main values of water ecosystem regulation services: water purification value, hydrological regulation value, water conservation value, and research and cultural value. In the model, the difficulty of clarifying parameters, such as the number of surface water resources and water consumption quota in Dalian, can be expressed in discrete intervals based on their maximum and minimum values. The ITSP model of Dalian coupled with ecological value factors can be formulated as follows:

$$
\operatorname{maxf}^{ \pm}=\mathrm{f}_{1}^{ \pm}+\mathrm{f}_{2}^{ \pm}-\mathrm{f}_{3}^{ \pm}-\mathrm{f} /{ }_{3}^{ \pm}-\mathrm{f}_{4}^{ \pm}-\mathrm{f} /_{4}^{ \pm}-\mathrm{f}_{5}^{ \pm}
$$

where $\mathrm{f}^{ \pm}$is the total expected system benefit $\left(10^{4} \mathrm{CNY}\right)$ over the planning periods.

(1) Sectors of water utilization benefits:

$$
\mathrm{f}_{1}^{ \pm}=\sum_{\mathrm{j}=1}^{6} \sum_{\mathrm{k}=1}^{3} \sum_{\mathrm{t}=1}^{3} \mathrm{~L}_{\mathrm{t}} \cdot \mathrm{UNB}_{\mathrm{jkt}}^{ \pm} \cdot\left(\mathrm{IAW}_{\mathrm{jkt}}^{ \pm}+\mathrm{RW}_{\mathrm{jkt}}^{ \pm}\right)
$$

where $\mathrm{j}$ denotes the administrative region; $\mathrm{k}$ is the water use sectors $(\mathrm{k}=1$ for industry, $\mathrm{k}=2$ for municipal, $\mathrm{k}=3$ for agriculture, and $\mathrm{k}=4$ for the ecological environment); $\mathrm{t}$ is different periods in the planning horizon ( $t=1$ is phase $I, t=2$ is phase II, and $t=3$ is phase $\mathrm{III})$; $\mathrm{L}_{\mathrm{t}}$ is the length of period, which is fixed at 5 years; $\mathrm{UNB}_{\mathrm{jkt}}^{ \pm}$represents water-use benefit $\left(10^{4} \mathrm{CNY} / 10^{4} \mathrm{~m}^{3}\right) ; \mathrm{IAW}_{\mathrm{jkt}}^{ \pm}$represents the initial allocation of water resources $\left(10^{4} \mathrm{~m}^{3} /\right.$ year $)$; $\mathrm{RW}_{\mathrm{jkt}}^{ \pm}$represents the reused water usage $\left(10^{4} \mathrm{~m}^{3} /\right.$ year $)$.

(2) Ecological benefits:

$$
\begin{aligned}
\mathrm{f}_{2}^{ \pm}= & \sum_{\mathrm{t}=1}^{3} \sum_{\mathrm{m}=1}^{4} \mathrm{C}_{1} \cdot \mathrm{L}_{\mathrm{t}} \cdot \mathrm{A}_{\mathrm{mt}}^{ \pm}+\sum_{\mathrm{t}=1}^{3} \mathrm{~L}_{\mathrm{t}} \cdot \mathrm{C}_{2} \cdot\left(\sum_{\mathrm{m}=1}^{4} \mathrm{~A}_{\mathrm{mt}}^{ \pm} \cdot \mathrm{D}+\sum_{\mathrm{n}=1}^{24} \mathrm{~S}_{\mathrm{nt}}^{ \pm} \cdot \mathrm{Z}\right) \\
& +\sum_{\mathrm{t}=1}^{3} \sum_{\mathrm{m}=1}^{4} \mathrm{~L}_{\mathrm{t}} \cdot \mathrm{C}_{2} \cdot \mathrm{A}_{\mathrm{mt}}^{ \pm} \cdot \mathrm{V}_{\mathrm{mt}}^{ \pm}+\sum_{\mathrm{t}=1}^{3} \mathrm{~L}_{\mathrm{t}} \cdot\left(\sum_{\mathrm{m}=1}^{4} \mathrm{~A}_{\mathrm{mt}}^{ \pm}+\sum_{\mathrm{n}=1}^{24} \mathrm{~S}_{\mathrm{nt}}^{ \pm}\right) \cdot \mathrm{C}_{3}
\end{aligned}
$$

where $\mathrm{m}$ denotes types of wetland $(\mathrm{m}=1-4$ for riverine, coastal, marsh, and constructed wetlands, respectively), and $\mathrm{n}$ represents types of river $(\mathrm{n}=1-24$ for Biliu, Fuzhou, Dasha, Yingna, Zhuanghe, Huli, Diyin, Xiaosi, Geli, Zanzi, Qingshui, Anzi, Weitao, Yongning, Fudu, Langu, Dengsha, Sanshili, Shihe, Qingyun, Beida, Xiaogushan, Muchengyi, and Malan rivers, respectively). $C_{1}$ is the scientific and cultural value of wetlands per $\mathrm{m}^{2}$, which is $0.382 \mathrm{CNY} / \mathrm{m}^{2} . \mathrm{A}_{\mathrm{mt}}^{ \pm}$and $\mathrm{S}_{\mathrm{nt}}^{ \pm}$denote wetland and river areas $\left(10^{4} \mathrm{~m}^{2}\right)$, respectively. $C_{2}$ represents the cost of the reservoir project, which is $0.67 \mathrm{CNY} / \mathrm{m}^{3} . \mathrm{C}_{3}$ is the value of wetland 
and water body degrading pollution, taking $2.81 \mathrm{CNY} / \mathrm{m}^{2} . \mathrm{Z}$ represents the normal water level in the study region, which is $2.5 \mathrm{~m}$. D is the maximum water storage difference, which is $2 \mathrm{~m}$.

(3) Sectors of water shortage penalty:

$$
\mathrm{f}_{3}^{ \pm}=\sum_{\mathrm{j}=1}^{6} \sum_{\mathrm{k}=1}^{3} \sum_{\mathrm{t}=1}^{3} \sum_{\mathrm{h}=1}^{3} \mathrm{~L}_{\mathrm{t}} \cdot \mathrm{p}_{\mathrm{h}} \cdot \mathrm{PNB}_{\mathrm{jkt}}^{ \pm} \cdot \mathrm{DW}_{\mathrm{jkth}}^{ \pm}
$$

where $h$ represents various runoff scenarios in every period $(h=1$ is low scenarios, $h=2$ is medium scenarios, $\mathrm{h}=3$ is high scenarios); $\mathrm{P}_{\mathrm{h}}$ denotes the occurrence probability of scenario $\mathrm{h}$; $\mathrm{PNB}_{\mathrm{jkt}}^{ \pm}$represents the reduction of net benefit to sector $\mathrm{k}$ per unit of water resource not delivered $\left(10^{4} \mathrm{CNY} / 10^{4} \mathrm{~m}^{3}\right)$; $\mathrm{DW}_{\mathrm{jkth}}^{ \pm}$is the allocation deficit of the surface water environment of Dalian that does not meet the initial water resource quotas of sector $\mathrm{k}$ during period $\mathrm{t}$ in region $\mathrm{j}$ under scenario $\mathrm{h}\left(10^{4} \mathrm{~m}^{3}\right.$ /year).

(4) Penalty for lack of ecological water:

$$
\mathrm{f}_{3}^{\prime \pm}=\sum_{\mathrm{t}=1}^{3} \sum_{\mathrm{h}=1}^{3} \mathrm{~L}_{\mathrm{t}} \cdot \mathrm{p}_{\mathrm{h}} \cdot\left(\sum_{\mathrm{m}=1}^{4} \mathrm{DA}_{\mathrm{mt}}^{ \pm}+\sum_{\mathrm{n}=1}^{24} \mathrm{DS}_{\mathrm{nt}}^{ \pm}\right) \cdot \mathrm{PNA}_{\mathrm{t}}^{ \pm}
$$

where $\mathrm{DA}_{\mathrm{mt}}^{ \pm}$and $\mathrm{DS}_{\mathrm{nt}}^{ \pm}$represent the missing area of various types of wetlands and rivers that did not meet the ecological requirements during period $\mathrm{t}\left(10^{4} \mathrm{~m}^{2} /\right.$ year $)$. $\mathrm{PNA}_{\mathrm{t}}^{ \pm}$is the water deficit loss in the ecosystem water department during period $\mathrm{t}\left(10^{4} \mathrm{CNY} / 10^{4} \mathrm{~m}^{2}\right)$.

(5) Sectors of water supply cost:

$$
\begin{aligned}
\mathrm{f}_{4}^{ \pm}= & \sum_{\mathrm{j}=1}^{6} \sum_{\mathrm{k}=1}^{3} \sum_{\mathrm{t}=1}^{3} \mathrm{~L}_{\mathrm{t}} \cdot\left(\mathrm{IAW}_{\mathrm{jkt}}^{ \pm}-\sum_{\mathrm{h}=1}^{3} \mathrm{p}_{\mathrm{h}} \cdot \mathrm{DW}_{\mathrm{jkth}}^{ \pm}\right) \cdot \mathrm{CW}_{\mathrm{jkt}}^{ \pm} \\
& +\sum_{\mathrm{j}=1}^{6} \sum_{\mathrm{k}=1}^{3} \sum_{\mathrm{t}=1}^{3} \mathrm{~L}_{\mathrm{t}} \cdot \mathrm{RW}_{\mathrm{jkt}}^{ \pm} \cdot \mathrm{CRW}_{\mathrm{jkt}}^{ \pm}
\end{aligned}
$$

where $\mathrm{CW}_{\mathrm{jkt}}^{ \pm}$represents the costs of water supply $\left(10^{4} \mathrm{CNY} / 10^{4} \mathrm{~m}^{3}\right)$; and $\mathrm{CRW}_{\mathrm{jkt}}^{ \pm}$is the cost of reused water supply $\left(10^{4} \mathrm{CNY} / 10^{4} \mathrm{~m}^{3}\right)$.

(6) Ecological water use cost:

$$
\mathrm{f}_{4}^{\prime \pm}=\sum_{\mathrm{t}=1}^{3} \mathrm{~L}_{\mathrm{t}} \cdot\left(\sum_{\mathrm{m}=1}^{4}\left(\mathrm{~A}_{\mathrm{mt}}^{ \pm}-\mathrm{DA}_{\mathrm{mt}}^{ \pm}\right)+\sum_{\mathrm{n}=1}^{24}\left(\mathrm{~S}_{\mathrm{nt}}^{ \pm}-\mathrm{DS}_{\mathrm{nt}}^{ \pm}\right)\right) \cdot \mathrm{SCW}_{\mathrm{t}}^{ \pm}
$$

where $\mathrm{SCW}_{\mathrm{t}}^{ \pm}$is the cost of water resources in the eco-environmental water department in period $\mathrm{t}\left(10^{4} \mathrm{CNY} / 10^{4} \mathrm{~m}^{2}\right)$.

(7) Wastewater treatment cost:

$$
\mathrm{f}_{5}^{ \pm}=\sum_{\mathrm{j}=1}^{6} \sum_{\mathrm{k}=1}^{4} \sum_{\mathrm{t}=1}^{3} \mathrm{~L}_{\mathrm{t}} \cdot\left(\begin{array}{l}
\mathrm{IAW}_{\mathrm{jkt}}^{ \pm}-\sum_{\mathrm{h}=1}^{3} \mathrm{p}_{\mathrm{h}} \cdot \mathrm{DW}_{\mathrm{jkth}}^{ \pm} \\
+\mathrm{RW}_{\mathrm{jkt}}^{ \pm}
\end{array}\right) \cdot \alpha_{\mathrm{jkt}} \cdot \mathrm{CWW}_{\mathrm{jkt}}^{ \pm}
$$

where $\mathrm{CWW}_{\mathrm{jkt}}^{ \pm}$represents the costs of wastewater treatment $\left(10^{4} \mathrm{CNY} / 10^{4} \mathrm{~m}^{3}\right)$; and $\alpha_{\mathrm{jkt}}$ represents the wastewater emission coefficient.

Subject to:

(1) Water supply constraints:

$$
\begin{gathered}
\sum_{\mathrm{k}=1}^{3}\left(\mathrm{IAW}_{\mathrm{jkt}}^{ \pm}-\mathrm{DW}_{\mathrm{jkth}}^{ \pm}\right) \leq \mathrm{AWQ}_{\mathrm{th}}^{ \pm} ; \forall \mathrm{t}, \mathrm{h} \\
\mathrm{DW}_{\mathrm{jkth}}^{ \pm} \leq \mathrm{IAW}_{\mathrm{jkt}}^{ \pm} ; \forall \mathrm{j}, \mathrm{k}, \mathrm{t}, \mathrm{h}
\end{gathered}
$$


where $\mathrm{AWQ}_{\mathrm{th}}^{ \pm}$represents available water resources in Dalian $\left(10^{4} \mathrm{~m}^{3} /\right.$ year $)$.

(2) Demand constraints of water use sectors:

$$
\begin{aligned}
& \mathrm{IAW}_{\mathrm{jkt}}^{ \pm}-\mathrm{DW}_{\mathrm{jkth}}^{ \pm}+\mathrm{RW}_{\mathrm{jkt}}^{ \pm} \geq \mathrm{WD}_{\text {min } \mathrm{jkt}}^{ \pm} ; \forall \mathrm{j}, \mathrm{k}, \mathrm{t}, \mathrm{h} \\
& \mathrm{IAW}_{\mathrm{jkt}}^{ \pm}-\mathrm{DW}_{\mathrm{jkth}}^{ \pm}+\mathrm{RW}_{\mathrm{jkt}}^{ \pm} \leq \mathrm{WD}_{\max \mathrm{jkt}}^{ \pm} ; \forall \mathrm{j}, \mathrm{k}, \mathrm{t}, \mathrm{h}
\end{aligned}
$$

where $\mathrm{WD}_{\text {minjkt }}^{ \pm}$and $\mathrm{WD}_{\text {maxjkt }}^{ \pm}$represent the minimum and maximum water resources requirement, respectively $\left(10^{4} \mathrm{~m}^{3}\right.$ /year).

(3) Regional wastewater treatment capacity constraints:

$$
\sum_{\mathrm{k}=1}^{2}\left(\mathrm{IAW}_{\mathrm{jkt}}^{ \pm}-\mathrm{DW}_{\mathrm{jkth}}^{ \pm}+\mathrm{RW}_{\mathrm{jkt}}^{ \pm}\right) \cdot \alpha_{\mathrm{jkt}} \leq \mathrm{ATW}_{\mathrm{jkt}}^{ \pm}, \forall \mathrm{j}, \mathrm{k}, \mathrm{t}, \mathrm{h}
$$

where $\mathrm{ATW}_{\mathrm{jkt}}^{ \pm}$represents the wastewater treatment capacity $\left(10^{4}\right.$ tons/year).

(4) Regional wastewater reuse capacity constraints:

$$
\sum_{\mathrm{k}=1}^{2}\left(\mathrm{IAW}_{\mathrm{jkt}}^{ \pm}-\mathrm{DW}_{\mathrm{jkth}}^{ \pm}+\mathrm{RW}_{\mathrm{jkt}}^{ \pm}\right) \cdot \alpha_{\mathrm{jkt}} \cdot \xi_{\mathrm{jkt}} \geq \sum_{\mathrm{k}=1}^{4} \mathrm{RW}_{\mathrm{jkt}}^{ \pm}, \forall \mathrm{j}, \mathrm{t}
$$

where $\xi_{j k t}$ is the wastewater reuse rate.

(5) Water environmental carrying capacity constraint:

$$
\sum_{\mathrm{j}=1}^{6} \sum_{\mathrm{k}=1}^{4}\left(\begin{array}{l}
\mathrm{IAW}_{\mathrm{jkt}}^{ \pm}-\mathrm{DW}_{\mathrm{jkth}}^{ \pm} \\
+\mathrm{RW}_{\mathrm{jkt}}^{ \pm}
\end{array}\right) \cdot \alpha_{\mathrm{jkt}}^{ \pm} \cdot \beta_{\mathrm{jkt}}^{ \pm} \cdot \mathrm{EC}_{\mathrm{krt}}^{ \pm} \cdot \mathrm{IDR}_{\mathrm{krt}} \cdot X_{\mathrm{ij}} \leq \mathrm{ALD}_{\mathrm{jrth}}^{ \pm}, \forall \mathrm{j}, \mathrm{r}, \mathrm{t}, \mathrm{h}
$$

where $r$ represents the type of pollutant ( $r=1$ for chemical oxygen demand (COD), $r=2$ for ammonia nitrogen $\left(\mathrm{NH}_{4}-\mathrm{N}\right), \mathrm{r}=3$ for total phosphorus $\left.\left(\mathrm{T}_{\mathrm{p}}\right)\right)$; $\mathrm{EC}_{\mathrm{krt}}^{ \pm}$represents the concentration of pollutant $\mathrm{r}$ after wastewater treatment (tons $/ 10^{4} \mathrm{~m}^{3}$ ); $\mathrm{IDR}_{\mathrm{krt}}$ represents the river load ratio; $\beta_{\mathrm{jkt}}$ is the wastewater concentration treatment coefficient; $X_{\mathrm{ij}}$ is the receiving ratio of water; and $\mathrm{ALD}_{\mathrm{irth}}^{ \pm}$represents the water environment carrying capacity (tons/year).

(6) Ecological value factor constraints:

$$
\begin{gathered}
\mathrm{A}_{\mathrm{mt}}^{ \pm}-\mathrm{DA}_{\mathrm{mt}}^{ \pm} \geq \mathrm{PRA}_{\mathrm{m} t}^{ \pm}, \forall \mathrm{m}, \mathrm{t} \\
\mathrm{S}_{\mathrm{nt}}^{ \pm}-\mathrm{DS}_{\mathrm{nt}}^{ \pm} \geq \mathrm{PRS}_{\mathrm{nt}}^{ \pm}, \forall \mathrm{n}, \mathrm{t} \\
\sum_{\mathrm{m}=1}^{4}\left(\mathrm{~A}_{\mathrm{mt}}^{ \pm}-\mathrm{DA}_{\mathrm{mt}}^{ \pm}\right) \cdot \mathrm{V}_{\mathrm{mt}}^{ \pm}+\sum_{\mathrm{n}=1}^{24}\left(\mathrm{~S}_{\mathrm{nt}}^{ \pm}-\mathrm{DS}_{\mathrm{nt}}^{ \pm}\right) \cdot \mathrm{V}_{\mathrm{nt}}^{ \pm} \leq \mathrm{IAS}_{\mathrm{t}}^{ \pm}, \forall \mathrm{t}, \mathrm{h}
\end{gathered}
$$

where $\mathrm{V}_{\mathrm{mt}}^{ \pm}$and $\mathrm{V}_{\mathrm{nt}}^{ \pm}$represent water storage capacity at normal water level $\left(10^{4} \mathrm{~m}^{3} / 10^{4} \mathrm{~m}^{2}\right)$, $\mathrm{PRA}_{\mathrm{mt}}^{ \pm}$and PRS $\mathrm{nt}_{\mathrm{nt}}^{ \pm}$, respectively, represent the minimum area of wetlands and rivers in the study area to ensure ecological functions $\left(10^{4} \mathrm{~m}^{2}\right)$; and $\mathrm{IAS}_{\mathrm{t}}^{ \pm}$represents the amount of water resources available in the ecological environment department $\left(10^{4} \mathrm{~m}^{3} /\right.$ year $)$.

(7) Other:

$$
\mathrm{DW}_{\mathrm{jkth}}^{ \pm}, \mathrm{RW}_{\mathrm{jkt}}^{ \pm} \mathrm{DA}_{\mathrm{m} t}^{ \pm}, \mathrm{DS}_{\mathrm{nt}}^{ \pm} \geq 0
$$

Using an interactive algorithm, the ITSP model can be transformed into two deterministic sub-models corresponding to the lower and upper bound values of the desired objective function. By solving the two sub-models, $\mathrm{DW}_{\mathrm{jkth}}^{-} \mathrm{DW}_{\mathrm{jkth}}^{+} \mathrm{RW}_{\mathrm{jkt}}^{+} \mathrm{RW}_{\mathrm{jkt}}^{-} \mathrm{DA}_{\mathrm{m}}^{-}, \mathrm{DA}_{\mathrm{mt}}^{+}, \mathrm{DS}_{\mathrm{nt}}^{-}, \mathrm{DS}_{\mathrm{nt}}^{+}$ were obtained, forming the final ITSP model as $\left[\mathrm{DW}_{\mathrm{jkth}}^{-}, \mathrm{DW}_{\mathrm{jkth}}^{+}\right],\left[\mathrm{RW}_{\mathrm{jkt}}^{-} \mathrm{RW}_{\mathrm{jkt}}^{+}\right]$, $\left[\mathrm{DA}_{\mathrm{mt}}^{-}, \mathrm{DA}_{\mathrm{mt}}^{+}\right],\left[\mathrm{DS}_{\mathrm{nt}}^{-}, \mathrm{DS}_{\mathrm{nt}}^{+}\right]$. 


\subsection{Model Parameters}

Table 1 lists the upper and lower bounds of the initial resource allocation of each water sector in Dalian. These were determined based on the latest last 10 years of regional water resource consumption in each sector and on the developmental planning for the region.

Table 1. Upper and lower bounds of the initial water resource allocation in Dalian $\left(10^{4} \mathrm{~m}^{3} /\right.$ year $)$.

\begin{tabular}{|c|c|c|c|c|}
\hline \multirow{2}{*}{ Regions } & \multirow{2}{*}{ Departments } & \multicolumn{3}{|c|}{ Periods } \\
\hline & & $t=1$ & $t=2$ & $t=3$ \\
\hline \multirow{4}{*}{ Four Districts } & $\mathrm{k}=1$ & 258 337 & $307 \sim 370$ & 314 395 \\
\hline & $\mathrm{k}=2$ & $6538 \sim 7699$ & $3148 \sim 8739$ & $8819 \sim 10,053$ \\
\hline & $\mathrm{k}=3$ & $122 \sim 132$ & $124 \sim 128$ & $116 \sim 122$ \\
\hline & $\mathrm{k}=4$ & $67 \sim 71$ & $61 \sim 93$ & $69 \sim 111$ \\
\hline \multirow{4}{*}{ Lvshunkou } & $\mathrm{k}=1$ & $3602 \sim 4254$ & $3684 \sim 4341$ & $3704 \sim 4383$ \\
\hline & $\mathrm{k}=2$ & 2992 3109 & $3063 \sim 3530$ & $3141 \sim 4060$ \\
\hline & $\mathrm{k}=3$ & $423 \sim 486$ & $430 \sim 471$ & $436 \sim 450$ \\
\hline & $\mathrm{k}=4$ & $161 \sim 263$ & $169 \sim 273$ & $160 \sim 296$ \\
\hline \multirow{4}{*}{ Jinpu } & $\mathrm{k}=1$ & $9301 \sim 10,313$ & $9116 \sim 10,331$ & $9856 \sim 10,534$ \\
\hline & $\mathrm{k}=2$ & 3073 3131 & $2828 \sim 3554$ & 3609 4089 \\
\hline & $\mathrm{k}=3$ & $2364 \sim 3120$ & $2408 \sim 3026$ & $2448 \sim 2894$ \\
\hline & $\mathrm{k}=4$ & $1282 \sim 1688$ & 1499 1731 & 1597 1761 \\
\hline \multirow{4}{*}{ Wafangdian } & $\mathrm{k}=1$ & $3266 \sim 3613$ & $3185 \sim 3819$ & $3447 \sim 4020$ \\
\hline & $\mathrm{k}=2$ & $1233 \sim 1728$ & $1400 \sim 1852$ & $1611 \sim 1987$ \\
\hline & $\mathrm{k}=3$ & $4067 \sim 4699$ & $4133 \sim 4557$ & $4192 \sim 4359$ \\
\hline & $\mathrm{k}=4$ & 1637 2542 & $1915 \sim 2576$ & $2167 \sim 2606$ \\
\hline \multirow{4}{*}{ Pulandian } & $\mathrm{k}=1$ & $889 \sim 1716$ & $804 \sim 1919$ & 817 2119 \\
\hline & $\mathrm{k}=2$ & $1814 \sim 2018$ & $1943 \sim 2291$ & $2086 \sim 2635$ \\
\hline & $\mathrm{k}=3$ & $6133 \sim 6622$ & $3226 \sim 6423$ & $5910 \sim 6143$ \\
\hline & $\mathrm{k}=4$ & $3015 \sim 3582$ & 3527 3788 & $3532 \sim 3888$ \\
\hline \multirow{4}{*}{ Zhuanghe } & $\mathrm{k}=1$ & $12,589 \sim 13,395$ & $12,974 \sim 13,418$ & $12,140 \sim 13,423$ \\
\hline & $\mathrm{k}=2$ & $923 \sim 5347$ & $389 \sim 6070$ & 1062 6983 \\
\hline & $\mathrm{k}=3$ & $4821 \sim 5410$ & $4897 \sim 5247$ & $4965 \sim 5019$ \\
\hline & $\mathrm{k}=4$ & $1606 \sim 2926$ & 1879 3941 & 2127 2952 \\
\hline
\end{tabular}

\section{Results and Discussion}

\subsection{Allocation of Water Resources in the Water Department}

Table 2 lists the initial optimal allocation of water resources in Dalian. It can be observed that the optimal allocation of water resources is close to the upper limit of the initial plan because more water allocation will bring more water resource benefits to various water-consuming sectors [24]. With the development of the society and economy, the annual water demand of the industrial and municipal domestic water sectors in different planning periods is gradually increasing. The development of Dalian is relatively balanced. Except for the ecological environment, the industrial water consumption in the study area accounts for about $43 \%$, and the municipal and agricultural water consumption accounts for $32 \%$ and $25 \%$, respectively. 
Table 2. The initial optimal allocation of water resources in Dalian $\left(10^{4} \mathrm{~m}^{3} /\right.$ year $)$.

\begin{tabular}{ccccc}
\hline \multirow{2}{*}{ Regions } & Sectors & & Periods & \\
\cline { 3 - 5 } & & $\mathbf{t}=\mathbf{1}$ & $\mathbf{t}=\mathbf{2}$ & $\mathbf{t}=\mathbf{3}$ \\
\hline \multirow{3}{*}{ Four Districts } & $\mathrm{k}=1$ & 337 & 370 & 395 \\
& $\mathrm{k}=2$ & 7699 & 8739 & 10,053 \\
& $\mathrm{k}=3$ & 132 & 128 & 122 \\
\hline \multirow{3}{*}{ Lvshunkou } & $\mathrm{k}=1$ & 4254 & 4341 & 4383 \\
& $\mathrm{k}=2$ & 3109 & 353 & 4060 \\
& $\mathrm{k}=3$ & 486 & 471 & 450 \\
\hline \multirow{3}{*}{ Jinpu } & $\mathrm{k}=1$ & 3132 & 10,431 & 10,534 \\
& $\mathrm{k}=2$ & 3120 & 3554 & 28089 \\
Wafangdian & $\mathrm{k}=3$ & 3613 & 3026 & 4020 \\
& $\mathrm{k}=1$ & 1728 & 3819 & 1987 \\
& $\mathrm{k}=2$ & 4699 & 4852 & 4359 \\
\hline \multirow{3}{*}{ Pulandian } & $\mathrm{k}=3$ & 1716 & 1919 & 2119 \\
& $\mathrm{k}=1$ & 2018 & 2291 & 2635 \\
& $\mathrm{k}=2$ & 6623 & 6423 & 6143 \\
\hline \multirow{2}{*}{ Zhuanghe } & $\mathrm{k}=3$ & 13,395 & 13,418 & 13,423 \\
& $\mathrm{k}=1$ & 4865 & 6070 & 6983 \\
& $\mathrm{k}=2$ & 5410 & 5247 & 5019 \\
\hline
\end{tabular}

Figures 4 and 5, respectively, show the amount of water reused by the industrial and municipal sectors in different planning periods. As shown in Figure 3, in regions Four Districts, Pulandian, and Zhuanghe, due to the higher water consumption rate and reclaimed water reuse rate of the industrial sector, the amount of reused water allocated gradually increased over time. For example, in region Zhuanghe, water reuse quotas were $27.02 \times 10^{4} \sim 54.37 \times 10^{4}, 32.78 \times 10^{4} \sim 63.44 \times 10^{4}$, and $37.76 \times 10^{4} \sim 68.65 \times 10^{4} \mathrm{~m}^{3} /$ year during the three periods. However, in regions Lvshunkou, Jinpu, and Wafangdian, water reuse quotas showed opposite trends for the three periods. The water reuse quotas were $18.80 \times 10^{4} \sim 38.93 \times 10^{4}, 17.44 \times 10^{4} \sim 37.35 \times 10^{4}$, and $14.83 \times 10^{4} \sim 31.96 \times 10^{4} \mathrm{~m}^{3} /$ year for region Lvshunkou; $4.36 \times 10^{4} \sim 5.97 \times 10^{4}, 3.98 \times 10^{4} \sim 4.89 \times 10^{4}$, and $3.14 \times 10^{4} \sim 4.74 \times 10^{4} \mathrm{~m}^{3} /$ year for region Jinpu; $28.32 \times 10^{4} \sim 71.20 \times 10^{4}, \quad 24.06 \times 10^{4} \sim 56.33 \times 10^{4}$, and $19.04 \times 10^{4} \sim 44.66 \times 10^{4} \mathrm{~m}^{3}$ /year for region Wafangdian, during the three periods, respectively. The first reason may be that the industrial sector has a relatively high water revenue; hence, the initial water quota in these two regions is close to the highest water demand, and there is no need for excess water resource allocation. The second is that increased water use means more wastewater is produced, which may exceed the existing wastewater treatment capacity. Therefore, under the condition of limited wastewater treatment capacity, a higher initial allocation of water resources will lead to water waste. As observed from Figure 5, the water reuse quota allocated to municipal life in the three planning periods was relatively small, especially in regions Lvshunkou and Jinpu. The reused water allocated to municipal sectors was even as low as $0.02 \times 10^{4} \mathrm{~m}^{3} /$ year. This may be because the municipal living sector has low demand for water reuse and low revenue; therefore, water is more likely to be allocated to the industrial sector with higher revenue. Since agricultural irrigation has higher requirements for reused water, it also has higher requirements for reused water treatment technologies. However, due to lower returns than the industrial sector, this is not considered. 


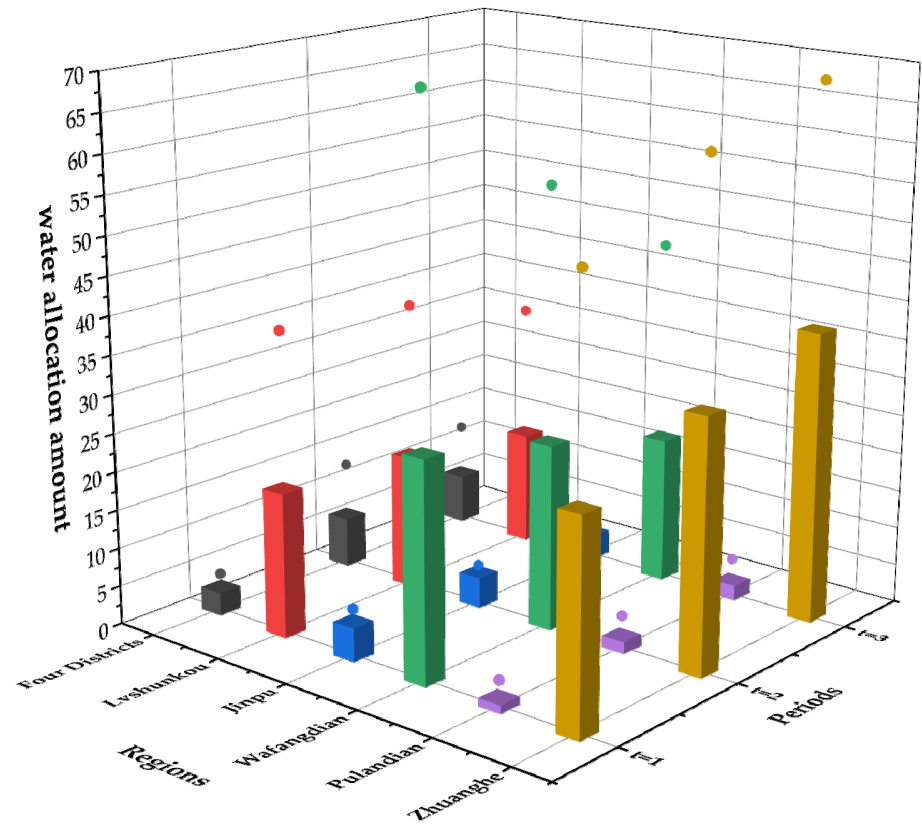

Figure 4. Reused water resource allocations for industry $\left(10^{4} \mathrm{~m}^{3} /\right.$ year $)$.

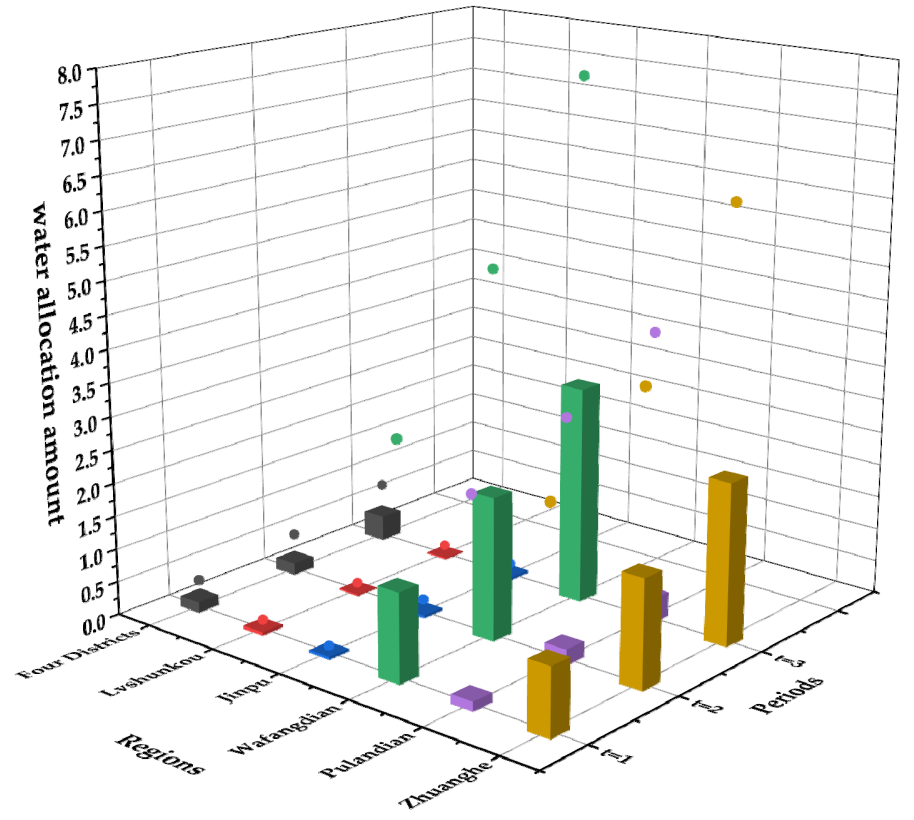

Figure 5. Reused water resource allocations for municipal use $\left(10^{4} \mathrm{~m}^{3} /\right.$ year $)$.

Tables 3-5 list the upper and lower bounds of water resource scarcity in the industrial, municipal, and agricultural sectors of each planning area during the three planning periods. As observed from the table, as the water resources increase, water shortages decrease. For example, in period 1, region Four Districts, water shortages of the industrial, municipal, and agricultural sectors in low, medium, and high water resource scenarios for the three periods were as follows: $311.02 \times 10^{4} \sim 320.57 \times 10^{4}, 149.79 \times 10^{4} \sim 245.81 \times 10^{4}$, and $101.59 \times 10^{4} \sim 201.70 \times 10^{4} \mathrm{~m}^{3}$ /year for the industrial sector; $4682.25 \times 10^{4} \sim 5695.01 \times 10^{4}$, $1489.38 \times 10^{4} \sim 5695.01 \times 10^{4}$, and $0.00 \sim 5695.01 \times 10^{4} \mathrm{~m}^{3} /$ year for the municipal sector; $2.80 \times 10^{4} \sim 59.73 \times 10^{4}, 0$, and $0 \mathrm{~m}^{3}$ /year for the agricultural sector. Although the industrial sector had the highest water efficiency, it consumed a lot of water. Therefore, as the planning period progressed, the demand and shortage for water continued to increase. The industrial sector in region Zhuanghe had the largest water shortage, for which 
the shortage under different water resource scenarios was $11,092.97 \times 10^{4} \sim 12,848.82 \times 10^{4}$, $594.47 \times 10^{4} \sim 3126.95 \times 10^{4}$, and $0.00 \sim 3126.95 \times 10^{4} \mathrm{~m}^{3} /$ year in period 1 , $11,886.10 \times 10^{4} \sim 15,872.69 \times 10^{4}, 382.03 \times 10^{4} \sim 3619.22 \times 10^{4}$, and $0.00 \sim 3619.22 \times 10^{4} \mathrm{~m}^{3} /$ year in period 2, $11,852.15 \times 10^{4} \sim 12,879.20 \times 10^{4}, 625.84 \times 10^{4} \sim 4879.20 \times 10^{4}$, and $0.00 \sim 4879.20 \times 10^{4} \mathrm{~m}^{3} /$ year in period 3. This is because, with the advancement of the planning period, the industry in region Zhuanghe had continuously increased water demand and water shortage. However, the lack of water in some other regions and water-consuming sectors did not show this regularity. For example, in region Jinpu, the municipal sector showed a low water resource scenario, and the water shortage was $2125.84 \times 10^{4} \sim 3128.79 \times 10^{4}, 1548.06 \times 10^{4} \sim 3552.92 \times 10^{4}$, and $884.61 \times 10^{4} \sim 2087.49 \times 10^{4} \mathrm{~m}^{3} /$ year in the three periods, respectively, showing a significant downward trend. This is because, under the current conditions of the development and utilization of water resources, over time, the water demand of various sectors has gradually increased, and the water safety of municipal sectors should be prioritized during the allocation of water resources.

Table 3. Upper and lower bounds of water resource deficit for each sector under different scenarios in period $1\left(10^{4} \mathrm{~m}^{3} /\right.$ year $)$.

\begin{tabular}{ccccc}
\hline \multirow{2}{*}{ Regions } & Sectors & \multicolumn{3}{c}{ Scenarios } \\
\cline { 3 - 5 } & & $\mathbf{h}=\mathbf{1}$ & $\mathbf{h}=\mathbf{2}$ & $\mathbf{h}=\mathbf{3}$ \\
\hline \multirow{3}{*}{ Four Districts } & $\mathrm{k}=1$ & $311 \sim 321$ & $150 \sim 246$ & $102 \sim 202$ \\
& $\mathrm{k}=2$ & $4682 \sim 5695$ & $1489 \sim 5695$ & $0 \sim 5695$ \\
& $\mathrm{k}=3$ & $3 \sim 60$ & 0 & 0 \\
\hline \multirow{3}{*}{ Lvshunkou } & $\mathrm{k}=1$ & $3881 \sim 4074$ & $3210 \sim 3959$ & $2783 \sim 3959$ \\
& $\mathrm{k}=2$ & $1104 \sim 3107$ & $0 \sim 3107$ & 0 \\
& $\mathrm{k}=3$ & 0 & 0 & 0 \\
Jinpu & $\mathrm{k}=1$ & $10,211 \sim 11,273$ & $8069 \sim 10,258$ & $7936 \sim 9211$ \\
& $\mathrm{k}=2$ & $2126 \sim 3129$ & $0 \sim 3129$ & $0 \sim 3129$ \\
Wafangdian & $\mathrm{k}=3$ & $2142 \sim 3099$ & $0 \sim 1119$ & 0 \\
\hline \multirow{3}{*}{ Pulandian } & $\mathrm{k}=1$ & $3140 \sim 3417$ & $2165 \sim 3308$ & $2038 \sim 3308$ \\
& $\mathrm{k}=2$ & $1267 \sim 1375$ & $873 \sim 1375$ & 0 \\
& $\mathrm{k}=3$ & $4173 \sim 4523$ & 0 & 0 \\
\hline \multirow{3}{*}{ Zhuanghe } & $\mathrm{k}=1$ & $1390 \sim 1707$ & $591 \sim 1688$ & 0 \\
& $\mathrm{k}=2$ & $235 \sim 2012$ & $0 \sim 2012$ & 0 \\
& $\mathrm{k}=3$ & $3605 \sim 5323$ & $1569 \sim 2404$ & 0 \\
\hline & $\mathrm{k}=1$ & $11,093 \sim 12,849$ & $594 \sim 3127$ & $0 \sim 3127$ \\
& $\mathrm{k}=2$ & $3807 \sim 4856$ & $0 \sim 4856$ & 0 \\
& $\mathrm{k}=3$ & $2989 \sim 4686$ & $0 \sim 166$ & 0 \\
\hline
\end{tabular}

Table 4. Upper and lower bounds of water resource deficit for each sector under different scenarios in period $2\left(10^{4} \mathrm{~m}^{3} /\right.$ year $)$.

\begin{tabular}{ccccc}
\hline \multirow{2}{*}{ Regions } & Sectors & \multicolumn{3}{c}{ Scenarios } \\
\cline { 3 - 5 } & & $\mathbf{h}=\mathbf{1}$ & $\mathbf{h}=\mathbf{2}$ & $\mathbf{h}=\mathbf{3}$ \\
\hline \multirow{3}{*}{ Four Districts } & $\mathrm{k}=1$ & $303 \sim 337$ & $140 \sim 252$ & $140 \sim 235$ \\
& $\mathrm{k}=2$ & $3725 \sim 4035$ & $3725 \sim 4035$ & $0 \sim 4035$ \\
& $\mathrm{k}=3$ & $8 \sim 58$ & 0 & 0 \\
\hline \multirow{2}{*}{ Lvshunkou } & $\mathrm{k}=1$ & $4045 \sim 4203$ & $3524 \sim 4043$ & $3182 \sim 4043$ \\
& $\mathrm{k}=2$ & $1526 \sim 3529$ & $376 \sim 3529$ & $0 \sim 3529$ \\
& $\mathrm{k}=3$ & $230 \sim 320$ & 0 & 0 \\
\hline \multirow{2}{*}{ Jinpu } & $\mathrm{k}=1$ & $10,296 \sim 10,377$ & $10,125 \sim 10,377$ & $9977 \sim 10,318$ \\
& $\mathrm{k}=2$ & $1548 \sim 3553$ & $0 \sim 3553$ & $0 \sim 3553$ \\
& $\mathrm{k}=3$ & $1950 \sim 3000$ & $1022 \sim 1317$ & $0 \sim 340$ \\
\hline
\end{tabular}


Table 4. Cont.

\begin{tabular}{ccccc}
\hline \multirow{2}{*}{ Regions } & Sectors & \multicolumn{3}{c}{ Scenarios } \\
\cline { 3 - 5 } & & $\mathbf{h}=\mathbf{1}$ & $\mathbf{h}=\mathbf{2}$ & $\mathbf{h}=\mathbf{3}$ \\
\hline \multirow{3}{*}{ Wafangdian } & $\mathrm{k}=1$ & $3200 \sim 3567$ & $2320 \sim 3523$ & $2262 \sim 3523$ \\
& $\mathrm{k}=2$ & $1436 \sim 1542$ & $0 \sim 1542$ & 0 \\
& $\mathrm{k}=3$ & $3911 \sim 4361$ & 0 & 0 \\
\hline \multirow{3}{*}{ Pulandian } & $\mathrm{k}=1$ & $1891 \sim 1909$ & $794 \sim 1748$ & 0 \\
& $\mathrm{k}=2$ & $1247 \sim 2284$ & $0 \sim 2284$ & 0 \\
\hline \multirow{2}{*}{ Zhuanghe } & $\mathrm{k}=3$ & $3733 \sim 5332$ & $1413 \sim 2779$ & 0 \\
& $\mathrm{k}=1$ & $11,886 \sim 15,873$ & $382 \sim 3619$ & $0 \sim 3619$ \\
& $\mathrm{k}=2$ & $4014 \sim 6063$ & $0 \sim 6063$ & 0 \\
\hline
\end{tabular}

Table 5. Upper and lower bounds of water resource deficit for each sector under different scenarios in period $3\left(10^{4} \mathrm{~m}^{3} /\right.$ year $)$.

\begin{tabular}{ccccc}
\hline \multirow{2}{*}{ Regions } & Sectors & \multicolumn{3}{c}{ Scenarios } \\
\cline { 3 - 5 } & & $\mathbf{h}=\mathbf{1}$ & $\mathbf{h}=\mathbf{2}$ & $\mathbf{h}=\mathbf{3}$ \\
\hline \multirow{3}{*}{ Four Districts } & $\mathrm{k}=1$ & $333 \sim 364$ & $199 \sim 302$ & $170 \sim 265$ \\
& $\mathrm{k}=2$ & $4035 \sim 5045$ & $0 \sim 5045$ & $0 \sim 5045$ \\
& $\mathrm{k}=3$ & $13 \sim 61$ & 0 & 0 \\
\hline \multirow{3}{*}{ Lvshunkou } & $\mathrm{k}=1$ & $4160 \sim 4280$ & $3756 \sim 4079$ & $3492 \sim 4079$ \\
& $\mathrm{k}=2$ & $2057 \sim 4060$ & $270 \sim 4060$ & $0 \sim 4060$ \\
Jinpu & $\mathrm{k}=3$ & $156 \sim 245$ & 0 & 0 \\
& $\mathrm{k}=1$ & $10,420 \sim 10,430$ & $10,337 \sim 10,492$ & $10,221 \sim 10,464$ \\
& $\mathrm{k}=2$ & $885 \sim 2087$ & $0 \sim 2087$ & $0 \sim 2087$ \\
Wafangdian & $\mathrm{k}=3$ & $1453 \sim 2833$ & $732 \sim 1160$ & $0 \sim 364$ \\
\hline \multirow{3}{*}{ Pulandian } & $\mathrm{k}=1$ & $3601 \sim 3843$ & $3098 \sim 3843$ & $2533 \sim 3713$ \\
& $\mathrm{k}=2$ & $1649 \sim 1754$ & $0 \sim 1754$ & 0 \\
& $\mathrm{k}=3$ & $3628 \sim 4178$ & 0 & 0 \\
\hline \multirow{3}{*}{ Zhuanghe } & $\mathrm{k}=1$ & $2090 \sim 2107$ & $1965 \sim 2107$ & 0 \\
& $\mathrm{k}=2$ & $1020 \sim 2627$ & $1020 \sim 2627$ & 0 \\
& $\mathrm{k}=3$ & $4844 \sim 5651$ & $1064 \sim 4139$ & 0 \\
\hline & $\mathrm{k}=1$ & $11,852 \sim 12,879$ & $626 \sim 4879$ & $0 \sim 4879$ \\
& $\mathrm{k}=2$ & $4927 \sim 6975$ & $0 \sim 6975$ & 0 \\
& $\mathrm{k}=3$ & $1412 \sim 4028$ & 0 & 0 \\
\hline
\end{tabular}

\subsection{Analysis of Ecological Value Factors}

4.2.1. Analysis of Water Distribution in the Ecological Environment Department

Table 6 lists the initial water use scenarios for ecological environment sector of the administrative districts in Dalian. It was observed that the water consumption of the environment sector in each planning period gradually increased. Region Pulandian had the largest environmental water consumption, which was $3581.54 \times 10^{4}, 3787.75 \times 10^{4}$, and $3888.45 \times 10^{4} \mathrm{~m}^{3} /$ year in the three periods, and the environmental water consumption increased each year. The first reason for this may be the increasing importance of the protection of the water environment, and the second may be the increasing benefits received by the ecological environment sector, which has prompted more water resources to be allocated to the ecological environment sector. 
Table 6. The initial optimal allocation of water resources for ecological environment sector in Dalian $\left(10^{4} \mathrm{~m}^{3} /\right.$ year $)$.

\begin{tabular}{cccc}
\hline \multirow{2}{*}{ Regions } & \multicolumn{3}{c}{ Periods } \\
\cline { 2 - 4 } & $\mathbf{t = 1}$ & $\mathbf{t = 2}$ & $\mathbf{t}=\mathbf{3}$ \\
\hline Four Districts & 71 & 93 & 111 \\
Lvshunkou & 263 & 273 & 296 \\
Jinpu & 1688 & 1730 & 1761 \\
Wafangdian & 2542 & 2576 & 2606 \\
Pulandian & 3582 & 3788 & 3888 \\
Zhuanghe & 2926 & 2941 & 2952 \\
\hline
\end{tabular}

Figure 6 shows the amount of water reused by the ecological environment sector. As shown in the figure, over time, the reused water quota gradually increased. For example, in region Pulandian, the amount of water reused was $336.73 \times 10^{4} \sim 398.94 \times 10^{4}$, $361.97 \times 10^{4} \sim 427.80 \times 10^{4}$, and $408.96 \times 10^{4} \sim 483.08 \times 10^{4} \mathrm{~m}^{3} /$ year in the three periods. The ecological environment sector had increasing benefits from water use and a high water demand; therefore, after all sectors reach the minimum water requirements, priority should be given to the allocation of more reused water to the ecological environment sector. Regions Four Districts and Lvshunkou showed relatively low water reuse. In region Four Districts, the amount of water reused was $57.92 \times 10^{4} \sim 71.21 \times 10^{4}$, $82.37 \times 10^{4} \sim 105.93 \times 10^{4}$, and $93.05 \times 10^{4} \sim 119.88 \times 10^{4} \mathrm{~m}^{3}$ /year during the three periods. This may be due to the relatively low river runoff in regions Four Districts and Lvshunkou. In region Jinpu, there was a very small difference between periods 2 and 3 in the amount of reused water; $299.06 \times 10^{4} \sim 396.30 \times 10^{4}$ and $301.81 \times 10^{4} \sim 404.97 \times 10^{4} \mathrm{~m}^{3} /$ year, respectively. The reason may be that during period 2 in region Jinpu, the amount of water reused was sufficient to meet the water requirements, and excessive allocation caused water waste.

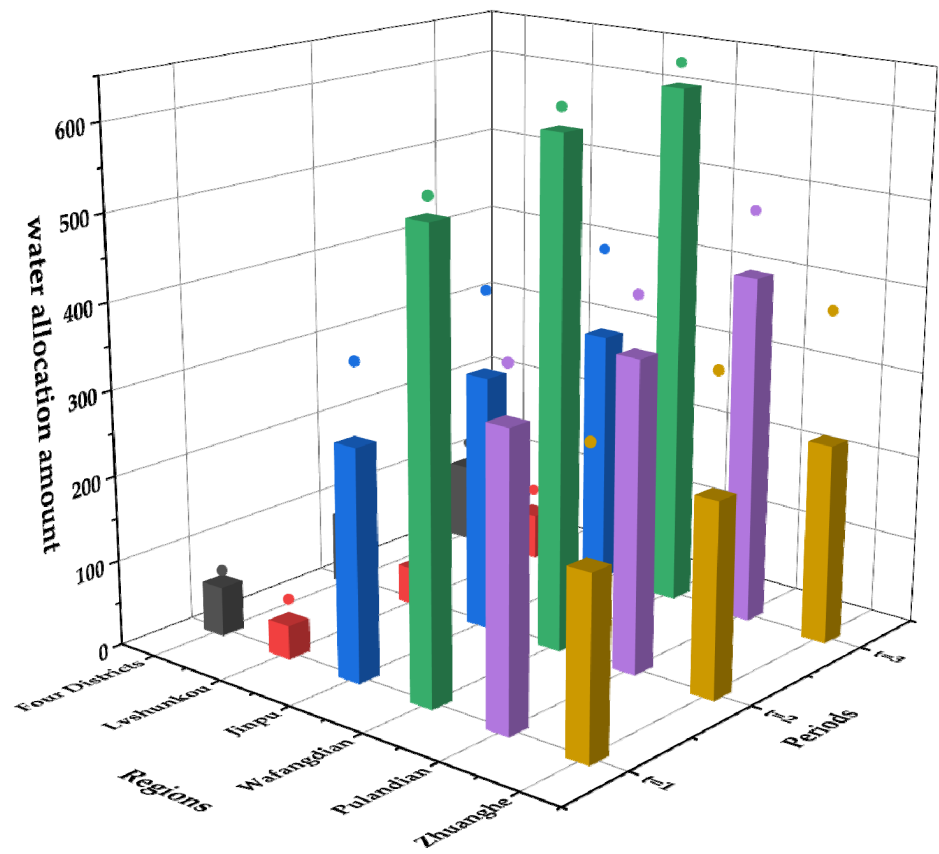

Figure 6. Reused water resource allocations for environment.

Tables 7-9 list the upper and lower bounds of water resource deficit for the ecological environment sector under different scenarios. As observed from the table, as the water resources increased, the amount of water shortages in the ecological environment sector decreased. For example, during period 1 in region Zhuanghe, the water deficits under different scenarios were $1415.75 \times 10^{4} \sim 1753.54 \times 10^{4}, 384.57 \times 10^{4} \sim 1753.34 \times 10^{4}$, 
and $0.00 \sim 153.54 \times 10^{4} \mathrm{~m}^{3} /$ year. Under the high water resources scenario, except for region Pulandian, the water shortage of the ecological environment sector was 0 , and the water shortage of the ecological environment sector in regions Four Districts and Lvshunkou were 0 under all water resource scenarios. This is because the quality of the water environment is closely related to the profitability of other sectors and ensuring the water consumption of the ecological environment sector is the basic prerequisite for economic development and the improvement of the quality of human life. This is in line with the objectives of China's 14th Five-Year Plan, which states that "we will adhere to the priority of ecology, promote ecological protection and economic development in a concerted manner, and create a beautiful China where people and nature live in harmony".

Table 7. Upper and lower bounds of water resource deficit for ecological environment sector under different scenarios in period 1.

\begin{tabular}{cccc}
\hline \multirow{2}{*}{ Regions } & \multicolumn{3}{c}{ Scenarios } \\
\cline { 2 - 4 } & $\mathbf{h}=\mathbf{1}$ & $\mathbf{h}=\mathbf{2}$ & $\mathbf{h}=\mathbf{3}$ \\
\hline Four Districts & 0 & 0 & 0 \\
Lvshunkou & 0 & 0 & 0 \\
Jinpu & $47 \sim 457$ & $0 \sim 457$ & 0 \\
Wafangdian & $657 \sim 734$ & 0 & 0 \\
Pulandian & $1416 \sim 1754$ & $385 \sim 1753$ & $0 \sim 154$ \\
Zhuanghe & $650 \sim 1521$ & 0 & 0 \\
\hline
\end{tabular}

Table 8. Upper and lower bounds of water resource deficit for ecological environment sector under different scenarios in period 2.

\begin{tabular}{cccc}
\hline Regions & \multicolumn{3}{c}{ Scenarios } \\
\cline { 2 - 4 } & $\mathbf{h}=\mathbf{1}$ & $\mathbf{h}=\mathbf{2}$ & $\mathbf{h}=\mathbf{3}$ \\
\hline Four Districts & 0 & 0 & 0 \\
Lvshunkou & 0 & 0 & 0 \\
Jinpu & $89 \sim 492$ & $0 \sim 492$ & 0 \\
Wafangdian & $693 \sim 768$ & 0 & 0 \\
Pulandian & $1616 \sim 1950$ & $428 \sim 1950$ & $0 \sim 1950$ \\
Zhuanghe & $651 \sim 1514$ & 0 & 0 \\
\hline
\end{tabular}

Table 9. Upper and lower bounds of water resource deficit for ecological environment sector under different scenarios in period 3.

\begin{tabular}{cccc}
\hline \multirow{2}{*}{ Regions } & \multicolumn{3}{c}{ Scenarios } \\
\cline { 2 - 4 } & $\mathbf{h}=\mathbf{1}$ & $\mathbf{h}=\mathbf{2}$ & $\mathbf{h}=\mathbf{3}$ \\
\hline Four Districts & 0 & 0 & 0 \\
Lvshunkou & 0 & 0 & 0 \\
Jinpu & $203 \sim 600$ & $0 \sim 600$ & 0 \\
Wafangdian & $843 \sim 916$ & 0 & 0 \\
Pulandian & $1764 \sim 2090$ & $681 \sim 2090$ & $0 \sim 2090$ \\
Zhuanghe & $785 \sim 1634$ & 0 & 0 \\
\hline
\end{tabular}

\subsubsection{Analysis of the Missing Area of the Aquatic Ecosystem}

The regulation service value created by aquatic ecosystems has a great relationship with the area of various types of aquatic ecosystems. The lack of ecosystem area indicates the damage of the ecosystem and the lack of ecosystem value, which is not conducive to the development of the society and economy. Figures 7 and 8 show the area of water loss in the ecosystem (various wetlands and rivers) during the three periods. It was observed that the loss of ecosystem area gradually decreased over time, and the loss of some rivers reached 0. For example, the area of marsh wetland loss was $55.69 \times 10^{4} \sim 59.96 \times 10^{4}$, $37.04 \times 10^{4} \sim 44.11 \times 10^{4}$, and $20.08 \times 10^{4} \sim 30.24 \times 10^{4} \mathrm{~m}^{2}$ in the three periods, respectively. 
In rivers 7 and 14, the amount of river area missing is 0 in the three periods. There is no increase in the area loss over time, because the amount of water used to maintain the normal development and relative stability of the aquatic ecosystem continued to increase, which reduced the area loss.

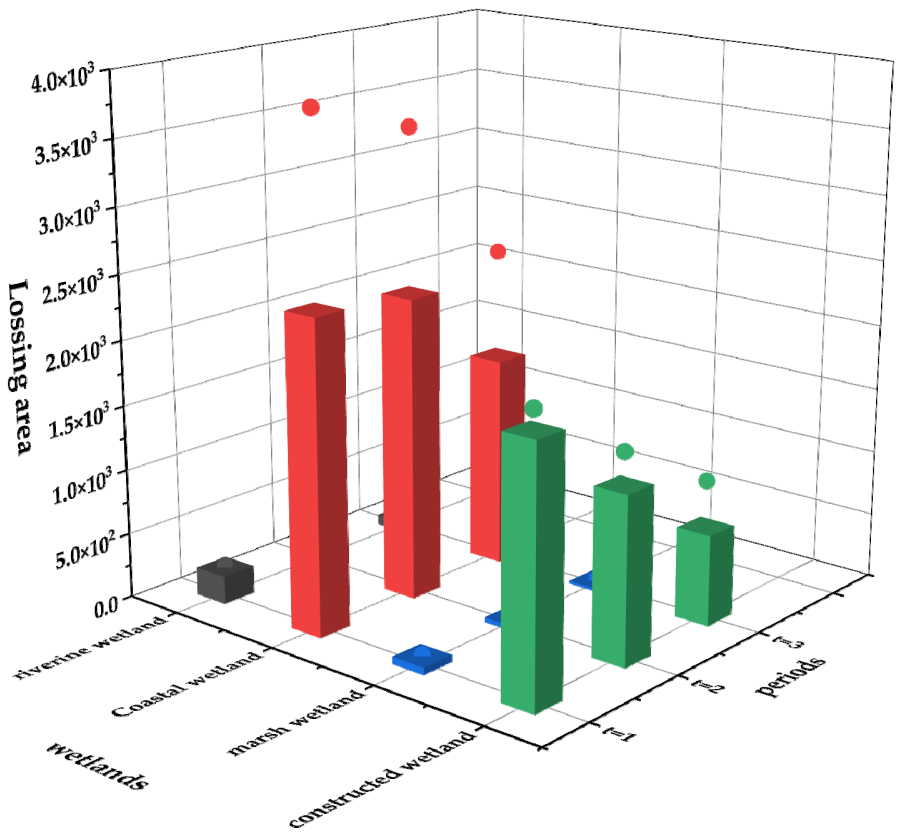

Figure 7. Loss of water ecosystem (wetland) area $\left(10^{4} \mathrm{~m}^{2}\right)$.

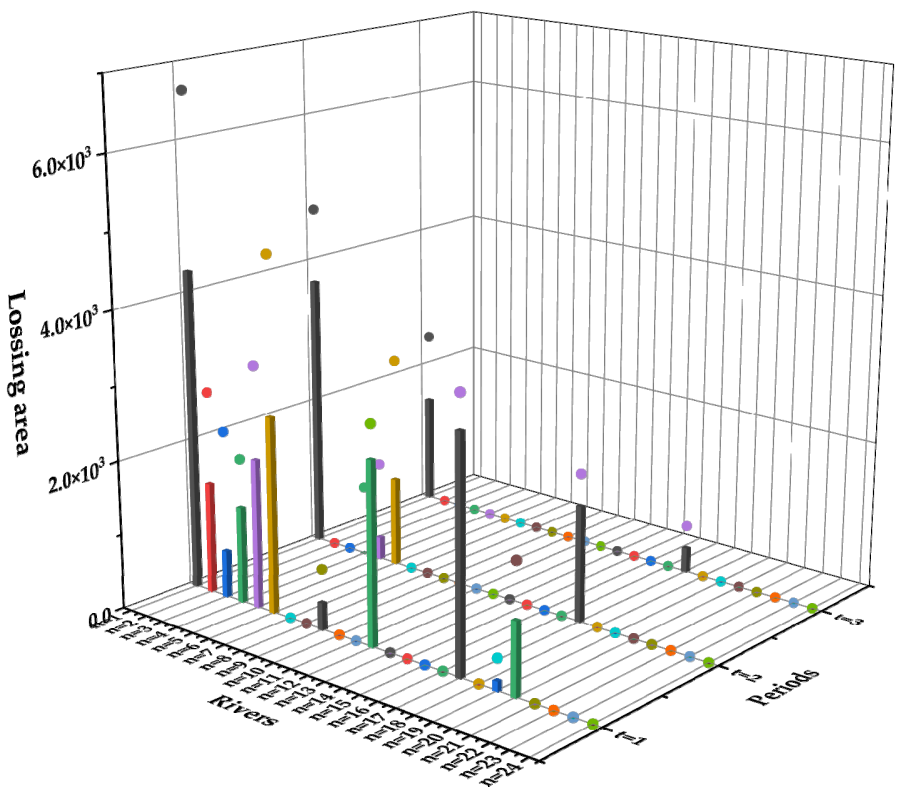

Figure 8. Loss of water ecosystem (river) area $\left(10^{4} \mathrm{~m}^{2}\right)$.

\subsubsection{Analysis of the Value of Ecological Regulation Services}

The optimal allocation model of water resources coupled with ecological value factors takes profit maximization as the objective function. The projected profit primarily includes the use of water resources and the regulation service value of the water ecosystem. The average annual ecological regulation service value of the three periods is shown in Figure 9. After the implementation of the optimal allocation of water resources, the overall value of Dalian's water ecosystem regulation services was on the rise, from 980,900 $\times 10^{4} \mathrm{CNY}$ in period 1 to $999,700 \times 10^{4} \mathrm{CNY}$ in period 3 . The values of the four types of indicators all 
grew steadily, with the highest proportion being the hydrological regulation value, which increased from $959,400 \times 10^{4} \mathrm{CNY}$ in period 1 to $972,100 \times 10^{4} \mathrm{CNY}$ in period 3 . This may be due to the gradual increase in the amount of water resources available for the ecological environment sector, the basic functions of the ecosystem are safeguarded and show a trend towards gradual improvement. Water ecosystems are creating more and more value and are in better environmental condition.

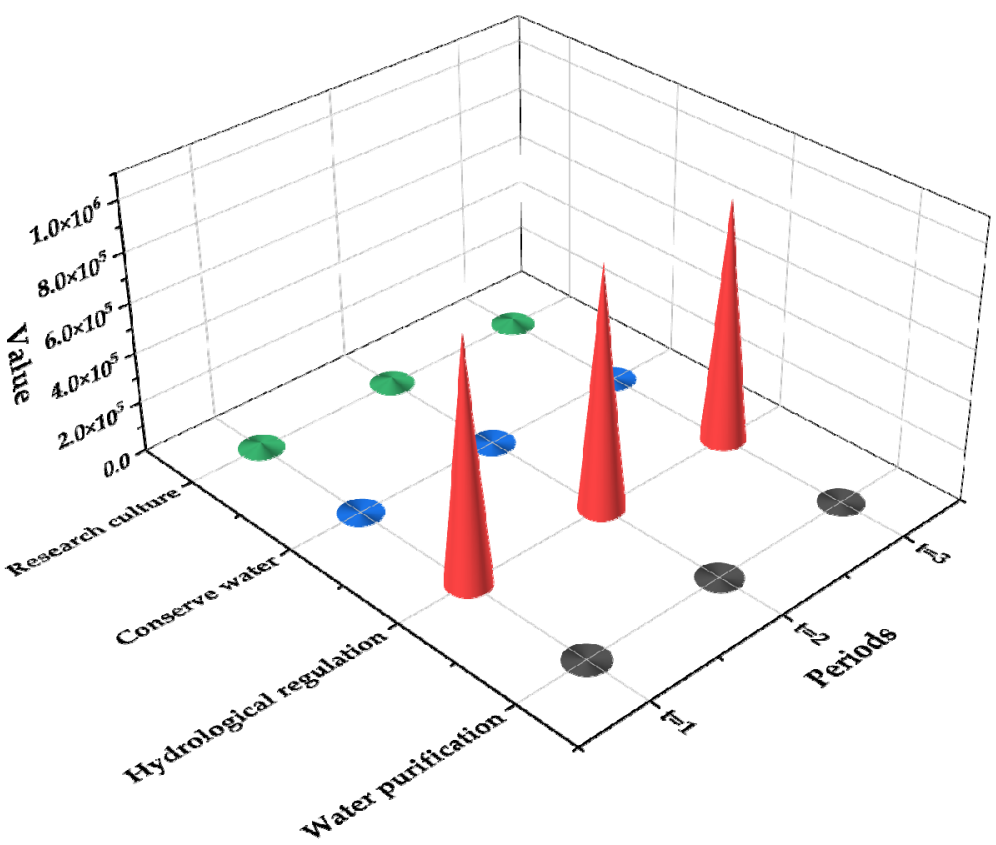

Figure 9. Ecological regulation service value $\left(10^{4} \mathrm{CNY} /\right.$ year $)$.

\subsection{Analysis of Regional Pollutant Emissions}

Figures 10-12 show COD, $\mathrm{NH}_{3}-\mathrm{N}$, and $\mathrm{T}_{\mathrm{p}}$ emissions from the industrial, municipal, and agricultural sectors, respectively. The discharge of pollutants does not exceed the maximum permissible discharge concentration of pollutants in freshwater waters of "the Liaoning Provincial Water Pollutant Discharge Standards for Coastal Areas", in addition, the discharge of various pollutants does not exceed the regional water environment capacity. Under the condition of implementing the optimal water resource allocation scheme coupled with ecological value factors, the emission of all kinds of pollutants in all sectors presented a downward trend over time. For the industrial sector, in region Wafangdian, the COD emissions were 502.10, 464.10, and 367.45 tons/year, $\mathrm{NH}_{3}-\mathrm{N}$ emissions were 78.48, 71.4, and 54.6 tons / year, and $\mathrm{T}_{\mathrm{p}}$ emissions were 37.10, 33.56, and 26.17 tons/year in the three periods, respectively. For the municipal sector, COD emissions were: 1888.43, 1745.54, and 1382.01 tons/year, $\mathrm{NH}_{3}-\mathrm{N}$ emissions were $254.43,231.49$, and 177.00 tons/year, and $\mathrm{T}_{\mathrm{p}}$ emissions were 54.27, 49.10, and 38.29 tons/year in the three periods, respectively. For the agriculture sector, COD emissions were 14,549.27, 13,448.37, and 10,647.61 tons/year, $\mathrm{NH}_{3}-\mathrm{N}$ emissions were $1217.00,1107.25$, and 846.64 tons/year, and $\mathrm{T}_{\mathrm{p}}$ emissions were $326.32,295.21$, and 230.23 tons / year in the three periods. This is in line with the objectives of China's 14th Five-Year Plan, which states that "by 2035, the total emissions of major pollutants will continue to be reduced, the efficiency of resource use will be significantly improved, and the first demonstration zone of a beautiful China will be basically built". However, $\mathrm{T}_{\mathrm{p}}$ emissions increased slightly in some areas. For example, in region Four Districts, $\mathrm{T}_{\mathrm{p}}$ emissions of the municipal sector were $458.09,470.13$, and 504.49 tons/year in the three periods, respectively. This may be because the domestic sewage collection and centralized treatment system were not perfect. Therefore, improving the domestic sewage centralized collection and treatment system will not only reduce the discharge of pollutants but also solve the water shortage problem. In regions Four Districts and 
Lvshunkou with high population density, the pollutants were mainly from the municipal sector, while the pollutants from the agricultural sector were relatively high in other regions. In some regions, the industrial sector consumed more water than the agricultural sector, but the sewage discharge was lower, which may be because the industrial sewage collection and treatment network is relatively perfect, and the sewage is generally discharged or reused after treatment.

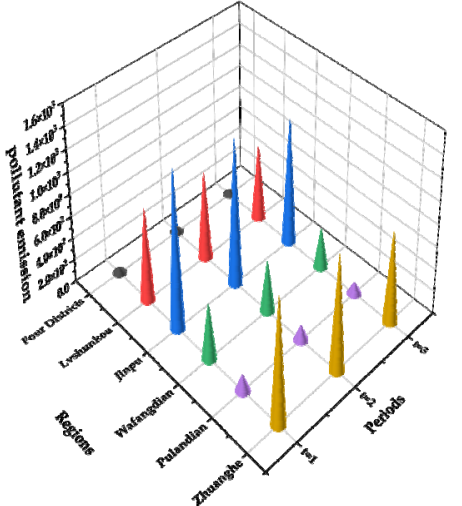

(a)

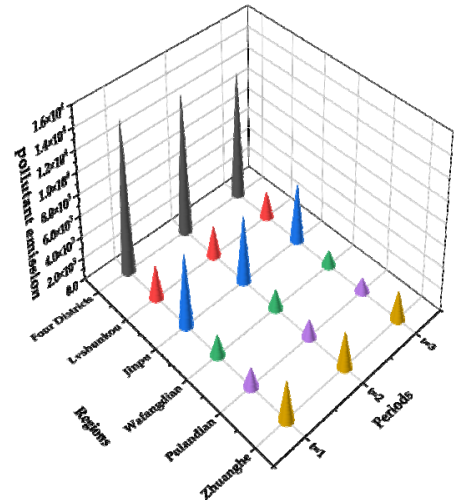

(b)

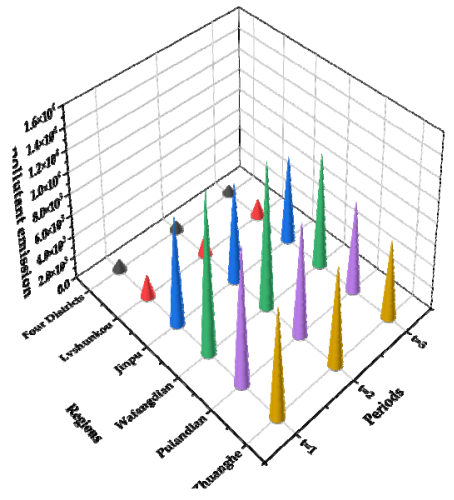

(c)

Figure 10. Chemical oxygen demand (COD) emissions of various sectors: (a) industry; (b) municipal; (c) agriculture (tons/year).

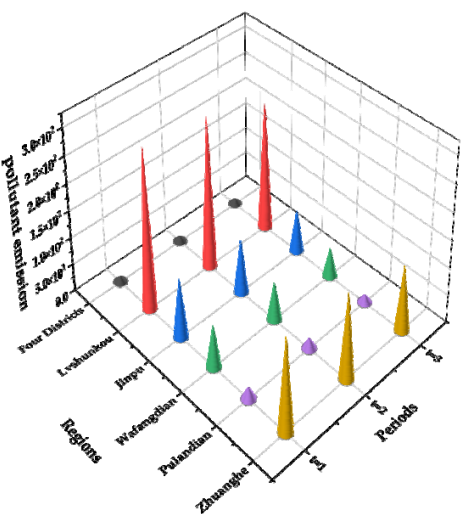

(a)

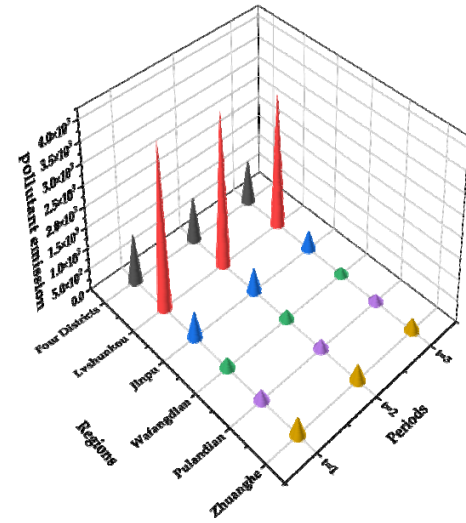

(b)

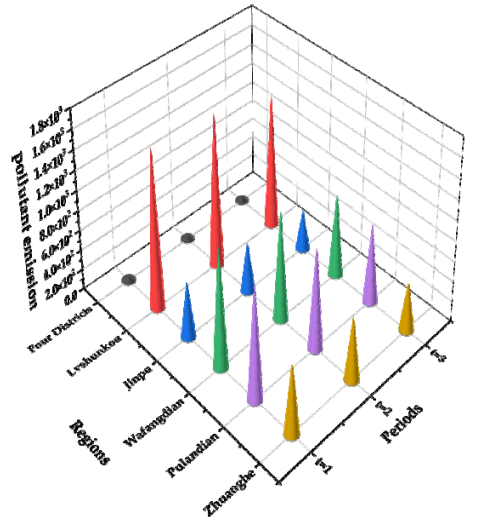

(c)

Figure 11. $\mathrm{NH}_{3}-\mathrm{N}$ emissions of various sectors: (a) industry; (b) municipal; (c) agriculture (tons/year).

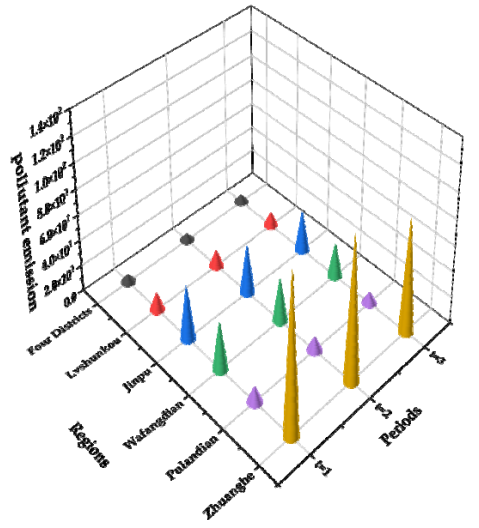

(a)

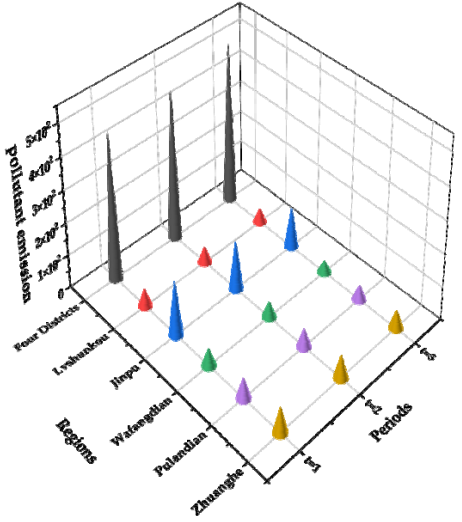

(b)

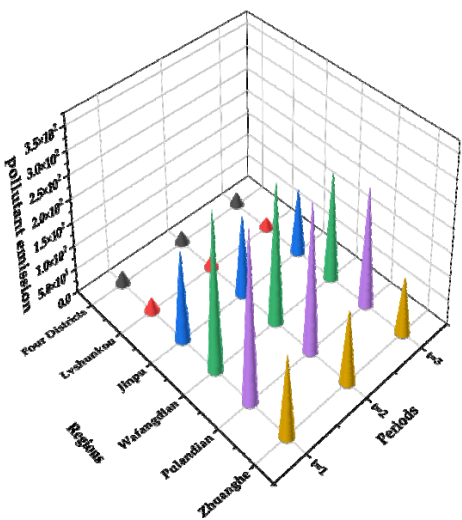

(c)

Figure 12. $\mathrm{T}_{\mathrm{p}}$ emissions of various sectors: (a) industry; (b) municipal; (c) agriculture (tons/year). 


\section{Conclusions}

This study established an inexact two-stage stochastic programming (ITSP) model of optimal allocation of water resources that couples water ecological value factors under uncertain conditions. This model is mainly to forecast and optimize the long-term prospects of Dalian, which is a typical water shortage in China. By integrating IPP and TSP methods, the model can manage uncertainties in interval values and probability distributions. By solving the ITSP model, on the premise of protecting the ecological value, the optimal allocation of water resources under different conditions to different water sectors and three periods was determined. In addition, data were also obtained on the lack of an aquatic ecosystem acreage, value of ecosystem service and the discharge of major water pollutants in various administrative regions. These results are constrained by the available water resources and provide the basis for the optimize the allocation of water resources and water quality management in Dalian. In addition, optimal allocation of water resources can improve the discharge of water pollutants in various administrative regions. The model results can be used to guide various departments in Dalian to formulate an optimal water resources allocation scheme by considering ecological value factors. The study findings provide the basis and support for Dalian to achieve the social and economic development goals, use water resources efficiently, and improve ecosystem quality through the optimized allocation of water resources.

The purpose of this research was to establish an ITSP model to create a water resources management system in Dalian that combines ecological value factors with the optimal allocation of water resources, so as to realize the coordinated development of social economic benefits and ecological benefits, and conducive to the synergistic efficiency of socio-economic and ecological water consumption, and it can also be applied to other regions with water shortages. Although the ITSP model can provide optimal preset schedules and adjustments under different scenarios, it cannot measure decision-making risks, nor does it assess the impact of different water sources and climate change on the availability of water resources. Therefore, there is still considerable room for improvement.

Author Contributions: Methodology, J.Z.; software, J.Z.; validation, J.Z. and C.M.; data curation, J.Z.; writing—original draft preparation, J.Z.; writing-review and editing, J.Z., C.M., S.H. and W.L.; project administration, S.H.; funding acquisition, W.L. All authors have read and agreed to the published version of the manuscript.

Funding: This research was funded by the Natural Science Foundation of China, grant number 72050001.

Conflicts of Interest: The authors declare no conflict of interest.

\section{References}

1. Luo, Z.W.; Xie, Y.L.; Ji, L.; Cai, Y.P.; Yang, Z.F.; Huang, G.H. Regional agricultural water resources management with respect to fuzzy return and energy constraint under uncertainty: An integrated optimization approach. J. Contam. Hydrol. 2021, 242, 103863. [CrossRef]

2. Mianabadi, H.; Sheikhmohammady, M.; Mostert, E.; Van de Giesen, N. Application of the Ordered Weighted Averaging (OWA) method to the Caspian Sea conflict. Stoch. Environ. Res. Risk Assess. 2014, 28, 1359-1372. [CrossRef]

3. del Saz-Salazar, S.; Garcia-Rubio, M.A.; Gonzalez-Gomez, F.; Picazo-Tadeo, A.J. Managing Water Resources Under Conditions of Scarcity: On Consumers' Willingness to Pay for Improving Water Supply Infrastructure. Water Resour. Manag. 2016, 30, 1723-1738. [CrossRef]

4. Gorgoglione, A.; Crisci, M.; Kayser, R.H.; Chreties, C.; Collischonn, W. A New Scenario-Based Framework for Conflict Resolution in Water Allocation in Transboundary Watersheds. Water 2019, 11, 1174. [CrossRef]

5. Aldieri, L.; Brahmi, M.; Chen, X.H.; Vinci, C.P. Knowledge spillovers and technical efficiency for cleaner production: An economic analysis from agriculture innovation. J. Clean Prod. 2021, 320, 128830. [CrossRef]

6. Bai, Y.; Ochuodho, T.O.; Yang, J. Impact of land use and climate change on water-related ecosystem services in Kentucky, USA. Ecol. Indic. 2019, 102, 51-64. [CrossRef]

7. Fu, Q.; Zhao, K.; Liu, D.; Jiang, Q.X.; Li, T.X.; Zhu, C.H. The Application of a Water Rights Trading Model Based on two-Stage Interval-Parameter Stochastic Programming. Water Resour. Manag. 2016, 30, 2227-2243. [CrossRef]

8. Xie, Y.L.; Xia, D.H.; Huang, G.H.; Li, W.; Xu, Y. A multistage stochastic robust optimization model with fuzzy probability distribution for water supply management under uncertainty. Stoch. Environ. Res. Risk Assess. 2017, 31, 125-143. [CrossRef] 
9. Rezaei, F.; Safavi, H.R.; Zekri, M. A Hybrid Fuzzy-Based Multi-Objective PSO Algorithm for Conjunctive Water Use and Optimal Multi-Crop Pattern Planning. Water Resour. Manag. 2017, 31, 1139-1155. [CrossRef]

10. Li, X.; Kang, S.; Niu, J.; Du, T.; Tong, L.; Li, S.; Ding, R. Applying uncertain programming model to improve regional farming economic benefits and water productivity. Agric. Water Manag. 2017, 179, 352-365. [CrossRef]

11. Puy, A.; Muneepeerakul, R.; Balbo, A.L. Size and stochasticity in irrigated social-ecological systems. Sci. Rep. 2017, 7, 43943. [CrossRef]

12. Mo, S.; Duan, H.; Shen, B.; Wang, D. Interval Two-Stage Stochastic Integer Programming for Urban Water Resource Management under Uncertainty. J. Coast. Res. 2015, 73, 160-165. [CrossRef]

13. Xie, Y.L.; Huang, G.H.; Li, W.; Li, J.B.; Li, Y.F. An inexact two-stage stochastic programming model for water resources management in Nansihu Lake Basin, China. J. Environ. Manag. 2013, 127, 188-205. [CrossRef]

14. Ji, L.; Huang, G.H.; Huang, L.C.; Xie, Y.L.; Niu, D.X. Inexact stochastic risk-aversion optimal day-ahead dispatch model for electricity system management with wind power under uncertainty. Energy 2016, 109, 920-932. [CrossRef]

15. Niu, G.; Li, Y.P.; Huang, G.H.; Liu, J.; Fan, Y.R. Crop planning and water resource allocation for sustainable development of an irrigation region in China under multiple uncertainties. Agric. Water Manag. 2016, 166, 53-69. [CrossRef]

16. Li, M.; Guo, P.; Singh, V.P.; Zhao, J. Irrigation Water Allocation Using an Inexact Two-Stage Quadratic Programming with Fuzzy Input under Climate Change. J. Am. Water Resour. Assoc. 2016, 52, 667-684. [CrossRef]

17. Meng, C.; Wang, X.; Li, Y. An Optimization Model for Water Management Based on Water Resources and Environmental Carrying Capacities: A Case Study of the Yinma River Basin, Northeast China. Water 2018, 10, 565. [CrossRef]

18. He, W.; Yang, L.Z.; Li, M.H.; Meng, C.; Li, Y. Application of an Interval Two-Stage Robust (ITSR) Optimization Model for Optimization of Water Resource Distribution in the Yinma River Basin, Jilin Province, China. Water 2020, 12, 2910. [CrossRef]

19. Han, Y.; Huang, Y.F.; Wang, G.Q.; Maqsood, I. A Multi-objective Linear Programming Model with Interval Parameters for Water Resources Allocation in Dalian City. Water Resour. Manag. 2011, 25, 449-463. [CrossRef]

20. Hong, J. Risk assessment of water resources development and utilization in Dalian. Water Resour. Dev. Manag. 2020, 18-21+29. [CrossRef]

21. Ahmed, S.; Tawarmalani, M.; Sahinidis, N.V. A finite branch-and-bound algorithm for two-stage stochastic integer programs. Math. Program. 2004, 100, 355-377. [CrossRef]

22. Ji, L.; Sun, P.; Ma, Q.; Jiang, N.; Huang, G.-H.; Xie, Y.-L. Inexact Two-Stage Stochastic Programming for Water Resources Allocation under Considering Demand Uncertainties and Response-A Case Study of Tianjin, China. Water 2017, 9, 414. [CrossRef]

23. Zeng, X.T.; Li, Y.P.; Huang, G.H.; Yu, L.Y. Inexact Mathematical Modeling for the Identification of Water Trading Policy under Uncertainty. Water 2014, 6, 229-252. [CrossRef]

24. Jin, D.; Bian, Z. Research on the Accounting Method of Xuzhou Ecological Civilization Based on Emergy and GEP. China Land Sci. 2013, 27, 88-94. 